\title{
Chapter 3: The Orator as Exegete: Cassiodorus as a Reader of the Psalms
}

\section{Gerda Heydemann}

[Accepted manuscript of the chapter published in: Janet Nelson, Damien Kempf (eds.) Reading the Bible in the Early Middle Ages (London: Bloomsbury 2015) 19-42.]

\begin{abstract}
This paper is concerned with the interplay between biblical exegesis, classical rhetoric and politics in the commentary on the Psalms written by Cassiodorus during the Gothic wars ( $c$. 550 AD). It explores how Cassiodorus, a Roman senator and former political advisor to the Ostrogothic kings of Italy, deployed the techniques of classical rhetoric to define his role as an exegete and to establish a connection between the text of the psalms and the world of his sixth-century audience. Focusing on Cassiodorus' interpretation of a series of psalms dealing with communities in crisis, it highlights the ways in which he used the biblical text to reflect on issues such as the religious significance of war and crises, the proper attitude towards political and religious opponents, and the tension between divine and human justice. In so doing, it seeks to contribute to our understanding of the commentary's place within the context of the political and religious debates during the age of Justinian.
\end{abstract}

Keywords.

biblical exegesis; rhetoric; Gothic wars; Cassiodorus; Expositio psalmorum

\section{Introduction}

In the spring of 544, Arator, the Roman subdeacon and former magistrate at the Ostrogothic court, recited his exegetical poem on the Acts of the Apostles in the church of San Pietro in Vincoli in Rome. The performance was a huge success: according to the report of the papal primicerius Surgentius, the reading of the two books took four days due to the enthusiasm of a crowd composed of the Roman clergy as well as laypeople, who frequently demanded the repetition of whole passages. ${ }^{1}$ The poem, dedicated to pope Vigilius (who may have been present during its recitation), celebrated pontifical authority and the importance of Rome as a Christian

\footnotetext{
1 The so-called Praefatio Surgentii, which is transmitted among the prefatory material of Arator's text in many of the manuscripts, explains how the poem was formally presented to Vigilius and deposited in the papal scrinium before the public reading. The text is given in McKinlay's edition of Arator's work: Arator, De Actibus apostolorum, ed. Arthur P. McKinlay, CSEL 72 (Vienna: Verlag der ÖAW, 1951), p. xxviii. For discussion, see Claire Sotinel, 'Arator, un poète au service de la politique du pape Vigile?’, Mélanges de l'École Française de Rome, 101 (1989), 805-20 (esp. 805-08). This article was written in the context of the SFB 'Visions of Community', funded by the Austrian Science Fund (FWF; project F4202-G18). I would like to thank Jinty Nelson, Damien Kempf and the participants of the 'Bibles'workshop at Liverpool and the California Medieval History Seminar at UCLA, as well as Maximilian Diesenberger, Maya Maskarinec, Irene van Renswoude, and Graeme Ward for their helpful comments on earlier drafts of this paper.
} 
centre, which was protected by the apostle Peter himself. ${ }^{2}$ This was a highly political and a very timely message in the midst of the Gothic wars, when the Ostrogothic armies under King Totila were making significant advances against the imperial forces. As the threat of a renewed siege of the city must have seemed imminent, Arator ended his first book by evoking St Peter's powers to defend Rome's liberty and safety and to end the war. ${ }^{3}$

At about the same time, Cassiodorus, the former praetorian prefect of Ostrogothic Italy, was likewise engaged in biblical interpretation. Like Arator, Cassiodorus used the biblical text - in his case, the psalms - to evoke the early Christian history of Rome, albeit in a different way. In his commentary on Psalm 73, a psalm of lamentation traditionally associated with the destruction of the second temple in $70 \mathrm{CE}$, Cassiodorus took the fall of one holy city, Jerusalem, as an occasion to appraise the rise of another. ${ }^{4}$ As he explained, the pagan fabric of Rome had come to be overlaid by Christian shrines, and Rome's inhabitants had been transformed from a plebs superstitiosa, an unbelieving crowd, into members of a saintly city, a civitas sanctissima. Out of the psalm's depiction of the fallen Jerusalem, Cassiodorus moulded the image of Christian Rome. But he did not do so to convey a triumphalist narrative of Rome as the centre of the Christian world which could have served to reassure his audience in the way Arator's poem was probably intended to. Rather, he used the remaining commentary to reflect on the religious offences committed by the Romans and on the atrocities of war. Behind the psalmist's lamentation, Cassiodorus sought to discern his judgement on the conquerors, as well as the proper Christian reaction to victory and defeat.

The result of Cassiodorus' exegetical project, the Expositio psalmorum [hereafter EP], was very different from Arator's both in genre and purpose: it is an extensive verse-by-verse commentary

\footnotetext{
2 Sotinel, 'Arator', 816-20; Johannes Schwind, Arator-Studien, Hypomnemata 94 (Göttingen, Vandenhoek \& Ruprecht, 1990); Roger P.H. Green, Latin Epics of the New Testament. Juvencus, Sedulius, Arator (Oxford: OUP, 2006), 251-350; Richard Hillier, Arator on the Acts of Apostles. A Baptismal Commentary (Oxford: OUP, 1993).
}

3 Arator, De actibus apostolorum, I.1070-76: 'His solidata fides, his est tibi, Roma, catenis/ perpetuata salus; harum circumdata nexu/ libera semper eris; quid enim non vincula praestent/ quae tetigit qui cuncta potest absolvere? cuius/haec invicta manu vel religiosa triumpho/ moenia non ullo penitus quatientur ab hoste./ Claudit iter bellis, qui portam pandit in astris'. Cf. Schwind, Arator-Studien, 224-33; Green, Latin Epics, 317-21 and 343-50.

${ }^{4}$ Cassiodorus, Expositio psalmorum [EP], ed. Marc Adriaen, CCSL, 97-98 (Turnhout: Brepols, 1958), LXXIII. 3. All citations of the EP refer to this edition, all English translations are taken from Patrick Walsh, Cassiodorus: Explanation of the Psalms, 3 vols, Ancient Christian Writers 51-53 (New York: Paulist Press, 1990-91). Psalm numbers follow the Vulgate numbering; the psalm texts and translations are quoted directly from Cassiodorus' Expositio to ensure correspondence with the text of the commentary. A new edition of the EP by Patricia Stoppacci is in preparation, of which the first volume containing the praefatio has appeared: Cassiodoro: Expositio psalmorum. Tradizione manuscritta, fortuna,edizione critica, vol. 1, ed. Patricia Stoppacci, Edizione Nazionale dei Testi Mediolatini d'Italia 28 (Florence: Edizioni del Galuzzo, 2012). 
on the whole psalter, a 'book for the eye' more than one to be performed. ${ }^{5}$ Yet there are also very interesting similarities between the two exegetes and their projects. Cassiodorus shared with Arator both the background of a Roman aristocratic family and political experience in the service of the Ostrogothic rulers of Italy. While Arator, who had been comes domesticorum under Athalaric, left Ravenna to join the papal clergy sometime in the 530s, Cassiodorus remained at court right through the early years of the Gothic wars. ${ }^{6}$ He had acted as a quaestor to Theoderic, and later succeeded the philosopher Boethius as magister officiorum after the latter's downfall in 523. Under Theoderic's successor Athalaric he rose to the praetorian prefecture, the highest office in the Italian administration. The Variae, a collection of administrative and diplomatic letters published as a record of his political activities, are an important source of information about the practice and ideologies of government in sixth-century Italy. ${ }^{7}$ There is not much firm evidence regarding Cassiodorus' activities during the 540s. It is usually assumed that he left Italy after imperial forces had taken Ravenna and captured King Witigis in 540, and that he spent most of the ensuing decade in Constantinople, where he wrote the major part of the EP. ${ }^{8}$ He probably returned to Italy after the end of the war and the Pragmatic Sanction (554), to establish a monastic foundation in Squillace (Vivarium), which became famous as a centre of Christian learning.

As an exegete, Cassiodorus like Arator looked back on politically eventful decades, while being confronted with a turbulent political present. In this paper, I would like to explore how these experiences shaped his reading of the psalter and the exegetical choices he made in his commentary. In particular, I will suggest that it is through his use of classical rhetoric that we can understand how Cassiodorus the politician defined and took up his role as an exegete. I will focus

\footnotetext{
${ }^{5}$ James Halporn, 'Methods of reference in Cassiodorus', Journal of Library History, 16 (1981), 71-91, at 73.
}

${ }^{6}$ James O'Donnell, Cassiodorus (Berkeley: UC Press, 1979), remains the fullest study of Cassiodorus' life: see ibidem, 13-32, for biographical information; Maïeul Cappuyns, 'Cassiodore', in Dictionnaire d'bistoire et de géographie ecclésiastiques, XI (1949), cols 1349-1408; André van de Vyver, 'Cassiodore et son œuvre', Speculum, 6 (1931), 244-92. Cf. the papers in Sandro Leanza ed., Flavio Aurelio Magno Cassiodoro: Atti della settimana di studi (Soveria Mannelli: Rubbettino, 1986) and idem ed., Cassiodoro: dalla corte di Ravenna al Vivarium di Squillace (Soveria Mannelli: Rubbettino, 1993). For an excellent introduction into Cassiodorus' work and the scholarly debates associated with it, see Marc Vessey, 'Introduction', in Cassiodorus: Institutions of Divine and Secular Learning. On the Soul, trans. James Halporn, Translated Texts for Historians 42 (Liverpool: Liverpool University Press, 2004), 1-101.

7 Cassiodorus, Variae, ed. Theodor Mommsen, Monumenta Germaniae Historica: Auctores antiquissimi 12 (Berlin: Weidmann, 1894); partial Engl. trans. Samuel Barnish, Cassiodorus: Variae, Translated Texts for Historians 12 (Liverpool: Liverpool University Press, 1992).

8 O’Donnell, Cassiodorus, 105-07; Samuel Barnish, ‘The work of Cassiodorus after his conversion', Latomus, 48 (1989), 157-87, at 164; Angela Amici, 'Cassiodoro a Constantinopoli: da magister officiorum a religiosus vir', Vetera Christianorum, 42 (2005), 215-31, at 221-24. Cassiodorus is securely attested in Constantinople by 550 through a letter by pope Vigilius. Some scholars assume that he came to Constantinople only in 546, at which point Vigilius was brought to Constantinople to negotiate an agreement with the emperor about the Three Chapters. 
on his rhetorical approach to a series of psalms which deal with crises and calamities, to see how they served as a means of observing and reflecting on problems which were also relevant in his own sixth-century society. In so doing, I hope to contribute to our understanding of the social and political dimensions of Cassiodorus' exegetical project and its potential audiences.

\section{Cassiodorus and the Expositio psalmorum}

We unfortunately lack detailed information about the circumstances of the EP's publication, let alone about its reception by a specific audience which we have for Arator's poetry. ${ }^{9}$ It is difficult to establish a precise date for the work, but the scholarly consensus is that while Cassiodorus may have begun writing in the late 530s in Ravenna, the majority of the text was composed in the ensuing decade, probably in Constantinople, and completed around $550 .{ }^{10}$ The preface, a system of marginal notes designed to guide the reader through the material on the liberal arts and on Christian doctrine, as well as bibliographical information, were added during a phase of revision at Vivarium. ${ }^{11}$ Certainly, the text as we have it now is the result of a long process of composition and continuous revision, adapting it to shifting audiences and purposes. Nevertheless, by drawing attention to certain characteristic features of the text, as well as by placing it in the context of Cassiodorus' other known activities during the 540s and 550s, it is possible to make some assumptions about its initial aims and audience.

\footnotetext{
${ }_{9}$ On the EP, see above all Reinhard Schlieben, Cassiodors Psalmenexegese: Eine Analyse ibrer Methoden (Göppingen: Kümmerle, 1979); a shorter version was pubished as idem, Christliche Theologie und Philologie in der Spätantike: Die schulwissenschaftlichen Methoden der Psalmenexegese Cassiodors, Arbeiten zur Kirchengeschichte (Berlin: De Gruyter, 1974); O'Donnell, Cassiodorus, 131-76; Aldo Ceresa Gastaldo, 'Contenuto e metodo dell'Expositio psalmorum di Cassiodoro', Vetera Christianorum, 5 (1968), 61-71; Manlio Simonetti, 'L'Expositio psalmorum di Cassiodoro', in Cassiodorus: Rivista di studi sulla tarda anticbità, 4 (1998), 125-39. From a philological perspective, see Ulrike Hahner, Cassiodors Psalmenkommentar: Sprachliche Untersuchung, Münchener Beiträge zur Mediävistik und Renaissance-Forschung 13 (München: Arbeo-Ges., 1973); Mauro Agosto, Impiego e definizione di tropi e schemi retorici nell'Expositio psalmorum di Cassiodoro (Montella [Avellino]: Accademia Vivarium Novum, 2003); on the christology of the work: Paulo DeSimone, Cassiodoro e l'Expositio psalmorum: una lettura cristologica dei Salmi (Cosenza: Ed. Progetto, 2000).
}

10 O'Donnell, Cassiodorus, 134-36 and 168-72. I agree with O’Donnell that Vigilius' condemnation of the Three Chapters in his Iudicatum of 548 cannot serve a strict terminus ante quem. See further van de Vyver, 'Cassiodore', 27175; cf. also Schlieben, Cassiodors Psalmenexegese, 4-10 together with the remarks in Vessey, 'Introduction’, 35 n. 110.

11 On the different recensions, see van de Vyver, 'Cassiodore', 271-73; James Halporn, 'Cassiodorus' citations from the Cantica canticorum and the composition of the Expositio in psalmos', Revue bénédictine, 99 (1985), 169-84; idem, 'Methods of reference in Cassiodorus'. Patricia Stoppacci, in her recent edition of the preface, distinguishes between at least two distinct phases of revision in Vivarium ('Introduzione', 183-207. Cf. eadem, 'Stadi redazionali nella tradizione manoscritta dell'Expositio psalmorum di Cassiodoro. Modalità di transmissione e diffusione delle opere cassiodoree', Studi medievali ser. 3, 50 (2009), 499-559. Cassiodorus seems to have kept a working exemplar of the EP, to which he continued to add notes and corrections. Cf. also James Halporn, 'The editing of patristic texts: the case of Cassiodorus', Revue des études augustiniennes, 30 (1984), 107-26. 
In the preface, Cassiodorus retrospectively described how he had left the world of secular politics and administrative duties in Ravenna to 'immerse myself in the sweet words of salvation, after most bitter events'. ${ }^{12}$ This notion of conversio, of the transition from the world of the Ostrogothic court to the realm of scriptural studies and ecclesiastical politics has been much debated in modern scholarship; it seems clear, however, that for Cassiodorus, this did not entail a retreat from public life and political interests. ${ }^{13}$

There are a number of indications that Cassiodorus remained involved in the political and religious debates during the 540s and 550s, and that the EP was intended as a contribution to some of them. ${ }^{14}$ Cassiodorus, like Arator, dedicated his text to a pope, and although he did not specify his name, it seems plausible that the pater apostolicus mentioned in the preface can be identified as Vigilius. ${ }^{15}$ This fits well with the fact that Cassiodorus was as deeply concerned with questions of doctrine and orthodoxy in his exegesis as was Arator. ${ }^{16}$ The EP contains frequent polemics against 'Arians', that is, adherents of a homoean Christianity which was prevalent among the ruling elite in the Ostrogothic kingdom. Cassiodorus also reacted to the contemporary christological debates known as the 'Three Chapters Controversy' which disrupted the Mediterranean church during the reign of Emperor Justinian I. Even if it may not be possible to infer an exact date of the EP from its references to the Three Chapters Controversy, it is clear

12 EP, pr.: 'Repulsis aliquando in Rauennati urbe sollicitudinibus dignitatum et curis saecularibus noxio sapore conditis, cum psalterii caelestis animarum mella gustassem, id quod solent desiderantes efficere, auidus me perscrutator immersi, ut dicta salutaria suauiter imbiberem post amarissimas actiones'.

13 On the notion of a decisive break between Cassiodorus' two careers, the political and the religious, see Vessey, 'Introduction', 16-18, who speaks of a 'split biography'. Cf. the remarks by Averil Cameron, 'Cassiodorus deflated', Journal of Roman Studies, 71 (1981), 183-86. It is interesting to note that Arator expressed similar sentiments in his prefatory letter to pope Vigilius: Arator, Ep. ad Vigilium, lines 9-10: 'Ecclesiam subeo dimissa naufragus aula/Perfida mundani desero uela freti'. Cf. Hillier, Arator, 6, who notes that the 'sacred and the secular Arator might just as well be separate persons, so little do we know about the path which led the poet to Rome'.

14 See Barnish, 'Work of Cassiodorus', 158-66; Amici, 'Cassiodoro a Constantinopoli', 221-31; Agosto, Impiego e definizione, 18-21. Cf. the much debated article by Arnaldo Momigliano, 'Cassiodorus and the Italian culture of his time', in idem, Studies in Historiography (London: Weidenfeld and Nicolson, 1966), 181-210, with reference to Cassiodorus' lost Gothic history.

15 Cappuyns, 'Cassiodore', 1370; O’Donnell, Cassiodorus, 134; Barnish, 'Work of Cassiodorus', 178-79. Patricia Stoppacci, 'Le dediche nelle opere di Cassiodoro. Il "pater apostolicus" dell" "Expositio psalmorum", Filologia mediolatina, 17 (2010), 11-39, at 21-27 and 35-37, has recently reopened the debate by suggesting that Vigilius' successor Pelagius is the more likely dedicatee, thereby taking up an argument by Halporn, 'Cassiodorus' citations', 172-74. As she points out, the deliberate ambiguity of Cassiodorus' formulation may point to the text's multifunctionality and its adaptation for changing audiences.

${ }^{16}$ Schwind, Arator-Studien, 212-24; Green, Latin Epics, 313-16. 
that the debates leading up to the Council of Constantinople in 553 formed an important context for the work's composition. ${ }^{17}$

Another striking feature of the EP is its remarkable integration of biblical studies with classical arts. The commentary is interwoven with passages transmitting knowledge about the liberal arts, ranging from geometry or music to dialectic and, above all, rhetoric. It has therefore been called a 'textbook of the liberal arts'. ${ }^{18}$ This effort to transmit and integrate classical and Christian learning has important social and political implications in a cultural context where concepts of Romanness and Christian identity had to be redefined and adapted for a post-imperial world. In this sense, the EP can be viewed as one in a series of attempts by Cassiodorus to provide intellectual guidance to a (future) Latin-speaking elite, who needed to understand Roman political traditions and values, as well as orthodox (Nicene and Chalcedonian) Christian theology. ${ }^{19}$ Latin culture and Christian scriptural exegesis were the necessary foundations for the formation of such an elite. ${ }^{20}$ A concern for such a project is visible in Cassiodorus' collaboration with Pope Agapetus to create a Christian school, but also in many of the texts written in the 530s to 550s: the second book of the famous Institutions of Divine and Secular Learning, which according to Fabio Troncarelli was originally published as a separate treatise on the liberal arts; ${ }^{21}$ the models for political and administrative writing in the Variae together with the De Anima; and the Historia tripartita, a

${ }^{17}$ O’Donnell, Cassiodorus, 170, characterises the EP as a 'tract' on the Three Chapters Controversy; cf. below \$.

18 O’Donnell, Cassiodorus, 158. See further Schlieben, Cassiodorus Psalmenexegese, 189-236; Agosto, Impiego e definizioni; Franz Weissengruber, 'L'educazione profana nell'Expositio psalmorum di Cassiodoro', in Sandro Leanza ed., Cassiodoro: dalla corte di Ravenna al Vivarium di Squillace (Soveria Mannelli: Rubbettino, 1993), 61-72; Simonetti, 'L'expositio psalmorum', 128-30. On rhetoric specifically, see below, n. \$ (n 35).

19 Agosto, Impiego e definizione, 24-27; Fabio Troncarelli, Vivarium. I Libri, il destino, Instrumenta Patristica 33 (Turnhout: Brepols, 1998), 14-15 and 35-38; idem, 'L'ordo generis Cassiodororum e il programma pedagogico delle Institutiones', Revue des études augustiniennes, 35 (1989), 129-34; Barnish, 'Work of Cassiodorus'; Amici, 'Cassiodoro a Constantinopoli', 230-31; Giuseppe Aricò, 'Cassiodoro e la cultura latina', in ed. Sandro Leanza ed., Flavio Aurelio Magno Cassiodoro (Soveria Mannelli: Rubbettino, 1986), 154-78, at 158-59.

20 On the intellectual horizon of the aristocratic elite and its synthesis between Christian and classical education in sixth-century Italy, see Charles Pietri, 'Aristocratie et societé cléricale dans l'Italie chrétienne au temps d'Odoacre et de Théoderic', in János Harmatta ed., Proceedings of the VII th Congress of the International Federation of the Societies of Classical Studies, vol. 2 (Budapest: Akad. Kiadó, 1984), 231-49; cf. Massimiliano Vitiello, "Nourished at the Breast of Rome": The queens of Ostrogothic Italy and the education of the Roman elite', Rheinisches Museum für Philologie, 149 (2006), 398-412.

21 Troncarelli, Vivarium, 12-21. For overviews of the complicated history of the text and its modern interpretations, see Patricia Stoppacci and Paolo Gatti, 'Cassiodorus Senator', in Paolo Chiesa and Lucia Castaldi eds, La Trasmissione dei testi latini del Medioevo/Mediaeval Latin Texts and Their Transmission, 4 vols, Millenio Medievale 94 (Florence: Edizioni del Galluzzo, 2012), IV, 81-146, at 114-29; Vessey, 'Introduction', 39-42. Of course, the version in two books, where the textbook on the liberal arts was combined with a treatise on the study of Christian texts, continued to serve this purpose. 
compilation and Latin translation of three Greek church histories. The audiences of these different works may well have, at least partially, overlapped.

Most important for this paper is that Cassiodorus interpreted the psalter as a 'collection of speeches', as Ann Astell has underlined. ${ }^{22}$ Cassiodorus read the psalms as a former orator. For him, rhetoric was a means to establish a connection between the text of the psalms and the world of his sixth-century audience. An analysis of his rhetorical exegesis can not only point to the messages which Cassiodorus wished to communicate in his exegesis, but also show how he envisaged the social and political implications of the biblical text.

\section{The orator as exegete}

In order to understand how Cassiodorus' experience as a secular orator shaped his exegetical approach, it is useful to look briefly at his thinking on the social and political function of rhetoric as it emerges from the Variae. Andrea Giardina has drawn attention to the fact that the rhetorical quality of the Variae is a key to understanding their political function and purpose, rather than being a reason to dismiss them as an instance of 'literary vanity' or 'mere rhetorical flourish' devoid of any practical significance, as has sometimes been suggested. ${ }^{23}$ The Variae merit study not only for the information about the Ostrogothic administration contained in the individual letters of the collection, and about their immediate audience, but also as a literary whole. As such, they can be interpreted as a careful attempt to legitimate the actions of the Italian elite who had run the administration during the Ostrogothic period. As a record of lawful and well-functioning government, the Variae may well have been intended to convince readers of a particular interpretation of the Ostrogothic past as compatible with Roman imperial traditions, thereby also communicating an argument about how the future political organisation of post-war Italy should involve continuity with this past. $^{24}$

\footnotetext{
22 Ann Astell, 'Cassiodorus' commentary on the psalms as an ars rhetorica', Rhetorica, 17/1 (1999), 37-75, at 68.

23 Andrea Giardina, Cassiodoro politico (Roma: 'L'Erma' di Bretschneider, 2006), pp. 31-39; Jean-Louis Jouanaud, 'Pour qui Cassiodore a-t-il publié les "Variae"?', in Teoderico il Grande e i Goti d'Italia. Atti del XIII Congresso internazionale di studi dull'Alto Medioevo, Milano 2-6 novembre 1992, 2 vols (Spoleto: Centro di Studio, 1993), II, 721-42; Stéphane Gioanni, "La langue de "pourpre" et la rhétorique administrative dans les royaumes ostrogothique, bourgonde et franc (VIe-VIIIe siècles)', in François Bougard, Régine Le Jan and Rosamond McKitterick eds, La culture du baut Moyen Age, une question d'élites?, Collection Haut Moyen Âge (Turnhout: Brepols, 2009), 13-38. Contrast the rather impatient remarks on the rhetorical style of the Variae by O'Donnell, Cassiodorus, 100; cf. also Andrew Gillett, 'The purpose of Cassiodorus' Variae', in Alexander C. Murray ed., After Rome's Fall: Narrators and Sources of Early Medieval History. Essays presented to Walter Goffart (Toronto: University of Toronto Press, 1998), 37-50.

24 See Andrea Giardina, Cassiodoro politico, 25-46; idem, 'Cassiodoro politico e il progetto delle Variae', in Teoderico il Grande e i Goti d'Italia: Atti del XIII Congresso internazionale di studi sull'alto medioevo (Spoleto: Centro di Studio, 1993), 4576; Christina Kakridi, Cassiodors Variae. Literatur und Politik im ostgotischen Italien, Beiträge zur Altertumskunde 223
} 
For Cassiodorus, rhetoric was of tremendous importance for the legitimacy of rulership and the exercise of government. He ascribed almost king-like power to the quaestor, the person responsible at the royal court for the drafting of official documents and diplomatic correspondence, a position he himself had occupied under King Theoderic. ${ }^{25}$ The quaestor functioned as the king's voice (vox nostrae linguae): his task was to ensure that the population accepted the legal measures and political decisions taken by the king. Ideally, the coercive power of the state could be replaced by the voluntary consent achieved through the use of rhetoric (ut paene feriata sit districtio, ubi praevalet eloquentia fortitudo). ${ }^{26}$ When Cassiodorus - whether as a quaestor or in other official functions - put the traditional governmental language of the Roman res publica at the service of the royal court, he fulfilled an eminently political task on behalf of the Gothic rulers. His work helped to assert the power of the king, but also to ensure the loyalty of his subjects to the legal and moral order of their society. ${ }^{27}$ To a glorious ruler, Cassiodorus claimed, the art of persuasion was therefore even more important than the collection of taxes. ${ }^{28}$

Such an understanding of rhetoric as a means to negotiate and safeguard social and political consensus is reminiscent of classical Roman conceptions of rhetoric as the art of government, as

(Munich: Saur, 2005), esp.157-291. Samuel Barnish, 'Roman responses to an unstable world: Cassiodorus' Variae in context', in Centre for Mediaeval Studies ed., Vivarium in Context, Leonard Boyle (Vicenza: Pozzo, 2008), 7-22, stresses eastern political discourse (and its religious dimensions) as a backdrop for the Variae. Most recently, Shane Bjornlie, Politics and Tradition between Rome, Ravenna and Constantinople. A Study of Cassiodorus and the Variae, 527-554 (Cambridge: CUP, 2013), esp. 26-34 and 306-28, has suggested that the Variae were published in Constantinople after 540, and that the model of conduct of a bureaucratic elite presented there was intended to convince not only an Italian audience, but also the eastern bureaucracy at the court of Justinian. For the importance of Latin as a literary and administrative language in sixth-century Constantinople, see Averil Cameron, 'Old and New Rome. Roman studies in sixth-century Constantinople', in Philip Rousseau and Emmanuel Papoutsakis eds, Transformations of Late Antiquity. Essays for Peter Brown, (Farnham: Ashgate, 2009), 15-36. In this context, John Lydus' famous plea for the preservation of Latin as the backdrop of Roman tradition is worth mentioning (see ibidem, p. 21). See further Fergus Millar, 'Linguistic co-existence in Constantinople: Greek and Latin (and Syriac) in the Acts pf the Synod of 536 C.E.', Journal of Roman Studies, 99 (2009), 92-103; Brian Croke, Count Marcellinus and his Chronicle (Oxford: OUP, 2001), 82-93.

25 On this, see Giardina, Cassiodoro politico, 33-36 and 44-45.

26 Cassiodorus, Variae, VI. v. 1-3. Cf. also XI. pr. 5, on the quaestor Felix ('qui necessitates publicas eleganter implendo ad favorabilem opinionem suo potius labore perduxit'); VIII. xiii and xiv (on the eloquentia of the quaestor Ambrose).

27 As Cassiodorus put it when describing the office of the quaestor, he 'is known to admonish the people with their princes' mouth that they should love the right, hate the wrong, praise good men without ceasing, and zealously denounce the evil' (Variae, VI. v. 3). Cf. the general preface: Variae, pr. 10 ('recorrigis mores prauos regi auctoritate [...] timorem legibus reddis'); VIII. xiv. 2 (the quaestor as custos legum and promissor conservanda iustitiae).

28 Cassiodorus, Variae, IX. xxv. 3: 'Gloriosius quippe dominis praeconia sunt quam tributa, quia stipendium et tyranno penditur, praedicatio autem nisi bono principi non debetur’. 
they were formulated in the works of Cicero, for example. ${ }^{29}$ In the Variae (as well as in the Institutiones) Cassiodorus emphatically located himself within such a Ciceronian tradition. ${ }^{30} \mathrm{By}$ claiming continuity with Roman rhetorical culture in its late antique, and increasingly Christianised form, Cassiodorus was at the same time claiming continuity with the political culture of the Roman empire, where the exercise of power was tied to the moral code and traditional self-perception of an educated elite. ${ }^{31}$ The work of the orator (and not least Cassiodorus' own efforts) contributed to the cultural and political accommodation between Gothic rulers and Roman political elites and helped to forge consensus between different social groups in the kingdom. Grammar and rhetoric emerge as the markers of just and civilised rule; they serve to highlight the 'Romanness' of the Gothic regime as opposed to 'barbarian' rule. ${ }^{32}$ This was the message that Cassiodorus intended to convey through the combination of rhetoric and political ethos in the Variae. ${ }^{33}$ Given his responsibility for the well-being of the state, the

\footnotetext{
29 See Elaine Fantham, The Roman World of Cicero's De Oratore (Oxford: OUP, 2004), esp. 209-36 and 305-19; Joy Conolly, The State of Speech: Rhetoric and Political Thought in Ancient Rome (Princeton: Princeton University Press, 2007); Vicenzio Scarano Ussani, 'Romanus sapiens et civilis vir. Quintilian's political theory of the orator acting for the benefit of imperial power', in ed. Olga Tellegen-Couperus ed., Quintilian and the Law. The Art of Persuasion in Law and Politics (Leuven: Leuven University Press, 2003), pp. 287-301. For Christian adaptations of (Ciceronian) rhetoric and its relevance for manufacturing consent, see Robert Dodaro, Christ and the Just Society in the Thought of Augustine (Cambridge: CUP, 2004); Christian Tornau, Zwischen Rhetorik und Philosophie. Augustins Argumentationstechnik in De civitate Dei und ibr bildungsgeschichtlicher Hintergrund (Berlin: DeGruyter, 2006).
}

${ }^{30}$ Cassiodorus, Variae, XI. pr. 8; cf. VI. v. 3 (citing De Oratore); Cassiodorus, Institutiones, ed. Roger A. B. Mynors (Oxford, Clarendon Press, 1937), II. pr. 4 and II. ii. 10 (Cicero as 'Latinae eloquentiae lumen eximium'). While the chapter on rhetoric in the Institutiones concentrates on technical matters and forensic argumentation, Cassiodorus' definition of rhetoric as 'bene dicendi scientia in civilis quaestionibus' (Institutiones, II. ii.1), following Quintilian and Fortunatianus, also highlighted the political and juridical aspects of rhetorical practice. On Cassiodorus' reception of classical (Ciceronian) rhetoric, see Vessey, 'Introduction', 27-30 and 71-72; Louis Holtz, 'Échos de l'enseignement de la rhétorique antique dans les Institutiones de Cassiodore', in Ktema, 14 (1989), 301-08; James Halporn, 'After the schools: Grammar and rhetoric in Cassiodorus', in Carol Dana Lanham ed., Latin Grammar and Rhetoric: From Classical Theory to Medieval Practice (London and New York: Continuum, 2002), pp. 48-62; Aricò, 'Cassiodoro e la cultura latina', 158-66.

31 Peter Brown, Power and Persuasion in Late Antiquity: Towards a Christian Empire (Madison: University of Wisconsin Press, 1992); Averil Cameron, Christianity and the Rhetoric of Empire. The Development of Christian Discourse (Berkeley: University of California Press, 1991); Robert Kaster, Guardians of Language. The Grammarian and Society in Late Antiquity (Berkeley: University of California Press, 1988); Irene van Renswoude, The Rhetoric of Free Speech in Late Antiquity and the Early Middle Ages, Cambridge Studies in Medieval Life and Thought (Cambridge: CUP, forthcoming).

32 Cassiodorus, Variae, IX. xxi. 4: 'hac [grammatica, GH] non utuntur barbari reges [...]. Arma enim et reliqua gentes habent: sola reperitur eloquentia, quae Romanorum dominis obsecundat'; cf. IX. xxv. 2.

33 Giardina, Cassiodoro politico, 35-39. Cf. Marc Reydellet, La royauté dans la littérature latine de Sidoine Apollinaire à Isidore de Séville, Bibliothèque des Écoles françaises d'Athènes et de Rome 243 (Rome: Diffusion de Boccard, 1981), 207: 'la rhétorique [...] transforme la politique en une étique'. 
almost Ciceronian orator-statesman as depicted in the Variae had to meet high standards in his personal behaviour and moral integrity. ${ }^{34}$

In many ways, we can discern a similar understanding of the power of language and the importance of rhetoric in Cassiodorus' reading of the Psalter. The use of the techniques of classical rhetoric has often been noted as the most distinctive feature of Cassiodorus' exegesis. ${ }^{35}$ In the preface to the EP, where Cassiodorus reflected on the special quality of biblical eloquentia, he defined its purpose using Paul's letter to Timothy: 'ad docendum, ad arguendum, ad erudiendum, ad corrigendum in disciplina quae est iustitiae, ut perfectus sit homo Dei ad omne opus bonum instructus' (II Tim. iii.16-7). ${ }^{36}$ Building on the thought of Augustine, Cassiodorus developed a notion of Christian rhetoric in which the Bible was the focal point. According to this view, the secular orators had actually derived their art from the Bible itself; as a divinely inspired text, it represented the purest and most effective form of oratory. Scripture was therefore a privileged source for the study of rhetoric; at the same time, rhetorical knowledge was essential to its correct understanding and should be deployed for the analysis of the biblical elocutio. ${ }^{37}$ Throughout the commentary, Cassiodorus paid close attention to the precise wording and the literary shape of the biblical text. He carefully registered the occurence of figures and tropes such as climax, hyperbole or the targeted use of metaphor in the psalms, explaining the meaning of rhetorical terms to his readers. ${ }^{38}$ Most of the marginal signs which he later added to the text as a guide for readers in fact concerned the definition of such rhetorical terms, the etymology of

\footnotetext{
${ }^{34}$ Standards that were embodied not least by Cassiodorus himself, see Variae, IX. xxiv and IX. xxv. On the political ideal and moral ethos of the aristocratic bureaucrats as propagated in the Variae, see Kakridi, Cassiodors Variae, 36073; Reydellet, La royauté, 192-97 and 218-53; Troncarelli, 'L'ordo generis', 131-34; Jouanaud, 'Pour qui Cassiodore at-il publié; cf. Bjornlie, Politics and Tradition, 216-53, as well as 283-305 for a reading of De Anima in this regard. For the Christian and biblical dimension of this ideal, see Samuel Barnish, 'Sacred texts of the secular: writing, reading and hearing in Cassiodorus' Variae', Studia patristica, 38 (2001), 362-70, who speaks of the 'homiletic' quality' of the Variae. On the classical ideal of the orator as uir bonus dicendi peritus see Michael Winterbottom, 'Quintilian and the vir bonus', Journal of Roman Studies, 54 (1964), 90-97; Jacob Wisse, 'De Oratore: Rhetoric, philosophy, and the making of the ideal orator', in James M. May ed., Brill's Companion to Cicero: Oratory and Rhetoric (Leiden: Brill, 2002), 375-400; Fantham, Roman World, 305-26.
}

35 Astell, 'Cassiodorus' commentary'; Schlieben, Psalmenexegese, 40-93, 187-211; Ceresa-Gastaldo, 'Contenuto e metodo', 64-65.

${ }^{36}$ EP, pr. xv. See Mauro Agosto, 'Su Cassiodorus In psalm praef.15', Cassiodorus, 5 (1999), 289-301, at 294.

37 Antonio Quacquarelli, 'L'elocutio di Agostino nelle riflessioni di Cassiodoro', Augustinianum, 25 (1985), 385-403; Agosto, 'Su Cassiodoro', 295-98; idem, Impiego e definizione, 29-52; Weissengruber, 'L'educazione profana', 64-69.

38 Agosto, Impiego e definizioni, is a detailed study and source analysis of all the figures and tropes in the EP; see also Jean-Marie Courtès, 'Figures et tropes dans le psautier de Cassiodore', in Revue des études latines, 42 (1964), 361-75; Schlieben, Cassiodors Psalmenexegese, 202-05; Antonio Quacquarelli, 'Riflessioni di Cassiodoro sugli schemi della retorica attraverso i Salmi', Vetera Christianorum, 25 (1988), 67-93. 
words or the peculiarities of biblical language. ${ }^{39}$ With this approach, Cassiodorus followed a strand of biblical interpretation which was shaped by the tradition of the grammatical and rhetorical schools. He was particularly indebted to Augustine's theory of the artes an instrument for the study of scripture as formulated in De doctrina christiana. ${ }^{40}$

While the incorporation of rhetorical material into the EP certainly enhanced its encyclopedic character and its functionality as a 'textbook', it is important to note that this was not a purely scholastic exercise. Rather, Cassiodorus deployed rhetoric as an effective tool of interpretation and exegetical argument. Most remarkable in this regard is Cassiodorus' combination of rhetorical analysis with a specific exegetical technique, prosopological exegesis. ${ }^{41}$ Following a long established interpretative tradition, Cassiodorus assumed that the narrative voice, the 'I' of the psalm text, could be identified with various speakers. David, sometimes speaking with his own voice, sometimes assuming the person of Christ or of various Old Testament figures such as Moses, Job or Asaph, acted as a rhetor, performing a social role not unlike that outlined in the Variae. $^{42}$ It is easy to imagine that the practice of speaking ex persona aliena was of particular interest to Cassiodorus, who had himself often assumed the voices of others when writing in the name of rulers in the Variae. ${ }^{43}$

${ }^{39}$ Astell, 'Cassiodorus' commentary', 41-42; Halporn, 'Methods of reference'.

${ }^{40}$ Frances Young, 'The rhetorical schools and their influence on patristic exegesis', in Rowan Williams ed., The Making of Orthodoxy. Essays in Honour of Henry Chadwick (Cambridge: CUP, 1989), 182-99; Christoph Schäublin, 'The contribution of rhetoric to Christian hermeneutics', in Charles Kannengiesser ed., Handbook of Patristic Exegesis. The Bible in Ancient Christianity (Leiden and Boston: Brill, 2006), 149-63. On the Augustinian background and De Doctrina christiana, see among others the contributions in Duane Arnold and Pamela Bright eds, De Doctrina Christiana. A Classic of Western Culture (Notre Dame IN: University of Notre Dame Press, 1995); Karla Pollmann, Doctrina cbristiana. Untersucbungen zu den Anfängen der cbristlichen Hemeneutik unter besonderer Berücksicbtigung von Augustinus, De doctrina cbristiana (Freiburg, CH: Universitätsverlag, 1996); Peter Gemeinhardt, Das lateinische Christentum und die antike pagane Bildung (Tübingen: Mohr Siebeck, 2007), 337-49; James J. Murphy, Rhetoric in the Middle Ages. A History of Rhetorical Theory from Saint Augustine to the Renaissance (Berkeley: University of California Press, 1979), 47-64; and the classic study by Henri-Irenée Marrou, Saint Augustin et la fin de la culture antique: avec une Retractatio (Paris: E. de Boccard, 1958), 469-98, 505-40.

${ }^{41}$ Schlieben, Cassiodors Psalmenexegese, 40-94. On this exegetical technique Marie-Josèphe Rondeau, Les commentaires patristiques du psautier, III'- $V^{\ell}$ siècles, 2 vols, Orientalia Christiana Analecta, 219-20 (Roma: Pontificale Institutum Studiorum Orientalium, 1982). For Augustine, see Michael Fiedrowicz, Psalmus vox totius Christi: Studien zu Augustinus 'Enarrationes in Psalmos' (Freiburg i. Br.: Herder, 1997).

${ }^{42}$ Cassiodorus, however, rejected the opinion that there was more than one author of the psalms, following Augustine in arguing that David had indeed composed the whole psalter, see EP, pr. ii; Schlieben, Cassiodors Psalmenexegese, 14-16.

43 Cassiodorus, Variae, XI, pr. 6: 'ut qui decem libris ore regio sum locutus, ex persona propria non haberer incognitus [...]'. Cf. Vessey, 'Introduction', 19. 
For each psalm, Cassiodorus outlined the rhetorical setting in a separate section called a divisio, indicating speakers, narrative units and main topics as well as the audience addressed. ${ }^{44}$ He even undertook a detailed literary analysis of some psalms as orations according to the rules of the classical rhetorical handbooks. ${ }^{45}$ He identified in the psalter examples for the different types of oratory, that is, epideictic (speeches of praise or blame), judicial, and even deliberative (advisory speech). In his exegesis of the individual psalms, Cassiodorus used the models and terminology of rhetorical theory. Penitential psalms, for instance, consisted of an exordium, a beginning designed to assure the benevolence of the divine judge, followed by an appropriately dramatic and tearful narratio and an effectful conclusio. ${ }^{46}$ Often, he discerned behind biblical verses the patterns of argumentation familiar to forensic orators, such as the argumentum ab attributis personarum tractum, a necessitate or a laude rei laesi (arguments drawn from the attributes of persons, from necessity, or 'by the praise of the thing harmed'). ${ }^{47}$

Cassiodorus' commentary on Psalm 89 offers an example of this. Playing on the double meaning of the psalm's superscription - oratio Moysi hominis Dei - Cassiodorus characterised the text as an 'oratio, by which the Lord's anger is deferred, pardon gained, punishment avoided, and generous rewards obtained when he speaks with the Lord and gossips with the judge. ${ }^{48}$ In the following commentary, Cassiodorus analysed Moses' speech as a peculiar fusion between a prayer and judicial oratory, which he described using both the vocabulary of religious devotion and penance and the language of law and the courtroom. Moses spoke both as a praying individual and as a mediator between God and the Israelites, beseeching Him for mercy on behalf of his sinful people. Cassiodorus devoted careful attention to the rhetorical strategies deployed by Moses. Given the guilt of the Israelites, he begged the Lord to 'temper his justice with a little gentleness,

${ }^{44}$ Schlieben, Cassiodors Psalmenexegese, 20-38.

45 Astell, 'Cassiodorus' commentary', 42-62; Schlieben, Cassiodors Psalmenexegese, 205-11; Hahner, Cassiodors Psalmenkommentar, 65-71. On the three types of oratory in classical tradition, see George A. Kennedy, The Art of Rhetoric in the Roman World, 300 BC-AD 300 (Princeton: Princeton University Press, 1972), 7-23 and 509-11; Tomás Albaladejo, 'The Three types of speeches in Quintilian, Book III: Communicative aspects of the political and legal features of rhetorical discourse', in Olga Tellegen Couperus ed., Quintilian and the Law. The Art of Persuasion in Law and Politics, (Leuven: Leuven University Press, 2003), 50-58.

46 See, for example, his analysis in EP, vI. div.; EP, xxxI. div.; EP, CI. div.

${ }^{47}$ EP, vi. 9; EP, xxxI. 4; EP, LXXIII. 2.

${ }^{48} E P$, LXXXIX. tit.: 'In primis oratio posita est, per quam ira domini suspenditur, uenia procuratur, poena refugitur et praemiorum largitas impetratur, cum domino loquitur, cum iudice fabulatur, praesentem sibi facit quem uidere non praeualet et illum per eam placat, quem suis actibus uehementer exaggerat'. Cf. Astell, 'Cassiodorus' commentary', 62-63. 
so that he can be prevailed upon by those sinners with whom he was known to be justly angry. ${ }^{49}$ To achieve this end, Moses cleverly used the argumentum a laude iudicis, that is, to praise the judge in order to obtain his goodwill. ${ }^{50}$ But Cassiodorus emphasized not only Moses' rhetorical skills he also underlined his personal prestige and moral integrity, describing him as a 'most holy man', as a lawgiver, and as a person who had earned the privilege of intimate access and personal relations with God. ${ }^{51}$ Experienced as he was in placating an angered God, Moses emerges as the perfect model for a political and spiritual leader who skilfully negotiated between his community and its divine ruler.

As Ann Astell has emphasised, this reading of the psalms as orations reinforced the potential for identification inherent in the biblical text. ${ }^{52}$ The deliberate fusion between secular and biblical oratory adds a strong social and political dimension to Cassiodorus' exegesis. In what follows, I will explore this in more detail by concentrating on a series of speeches delivered by one of these biblical speakers, a certain Asaph. ${ }^{53}$ Asaph appears in the headings of various psalms and was interpreted by Cassiodorus as a spokesman of the Jewish people (or the synagogue), and as an allegory for the Christian church. ${ }^{54}$ Like Moses, he was a figure of considerable interest for Cassiodorus: an intellectual leader of his people, a teacher (and also, in a sense, a historian), capable of providing guidance and mediating between God and Israel. Some of his speeches are speeches to a community in crisis, meant to reprimand or exhort the Israelites or to offer consolation and guidance in times of war, oppression or religious upheaval. These speeches, then, provide good examples of Cassiodorus' understanding of the rhetoric of the psalter, and of the lessons he wanted his audience to draw from it.

\footnotetext{
${ }^{49}$ EP, LXXXIX. 13.

${ }^{50}$ EP, LXXXIX. 16.

${ }^{51}$ EP, LXXXIX. tit.

52 Astell, 'Cassiodorus' commentary’, 68.
}
53 The series of psalms associated with Asaph comprises psalms 49 and 72-82. Michael D. Goulder, The Psalms of Asaph and the Pentatench, Journal for the Study of the Old Testament Supplement Series 233 (Sheffield: Sheffield Academic Press, 1996); Beat Weber, 'Der Asaph-Psalter - eine Skizze', in Beat Huwyler, Hans-Peter Mathys and Beat Weber eds, Prophetie und Psalmen (Münster: Ugarti, 2001), 117-41.

${ }^{5}$ EP, LXXIII. tit.: 'congregatio quae nunc uocatur ecclesia', which is the typological counterpart of the populus Israelitarum. Cf. EP, LXXVIII. tit.: 'Asaph uero synagogam significat, quae tamen catholicae conuenire possit ecclesiae', and EP, XLIX, tit. for the interpretation of Asaph as an allegory for the Jewish synagogue as well as its Christian continuation. 


\section{Meditations in an Emergency: The Psalter and the Rhetoric of Crisis}

Psalm 73, a psalm of lamentation already cited at the beginning of this paper, was traditionally interpreted by Christian exegetes as a prophetic foretelling of the destruction of Jerusalem in 70 CE. ${ }^{55}$ This was an event charged with symbolic meaning, the interpretation of which had been contested between Christians and Jews, as well as among Christian intellectuals, for centuries. ${ }^{56} \mathrm{In}$ his commentary, Cassiodorus followed the traditional interpretation of the psalm, but in addition, he imagined a very vivid rhetorical setting: Asaph, the speaker of the psalm, was acting as a forensic orator, pleading with the divine judge for mercy on behalf of the beleaguered Israelites and asking God to destroy their enemies. ${ }^{57}$ This may seem a somewhat surprising exegetical choice, given that Cassiodorus clearly subscribed to the standard view that the fall of Jerusalem had been a divine punishment for the Jews' rejection of Christ. ${ }^{58}$ But he spent surprisingly little time on discussing the significance of the destruction of the temple as a potent sign of the transition of God's grace from the Jews to the gentiles. Instead, he focussed attention on Asaph's rhetorical efforts to defend Israel, which basically consisted of conjuring up God's anger against their enemies, the Romans. As will become clear, this served to undermine any connection between Christian triumphalism and Roman universalism to which the psalm might give rise.

The dramatic events narrated by the psalm must have easily suggested themselves for comparison with contemporary events as Cassiodorus was writing during the Gothic wars. With control over Rome and other Italian cities repeatedly changing hands between the different parties in the course of the war, the fall of Jerusalem, the 'quintessential siege', lingered in the back of people's minds as the backdrop against which to evaluate contemporary events. Flavius Josephus' Jewish

\footnotetext{
55 On the psalm, of which the dating and historical reference is controversial, see Michael Emmendörffer, Der ferne Gott. Eine Untersucbung der alttestamentarischen Volksklagelieder (Tübingen: Mohr, 1998), 77-102; Goulder, The Psalms of Asaph, 61-68; Ariane Cordes, Therese Hunsberger, and Erich Zöllner, 'Die Verwüstung des Tempels - eine Krise der Religion? Beobachtungen zum Volksklagepsalm 74 [73] und seiner Rezeption in der Septuaginta und im Midrash Tehillim [73]', in Johannes Hahn and Christian Ronning eds, Zerstörungen des Jerusalemer Tempels: Geschehen Wabrnehmung - Bewältigung (Tübingen: Mohr Siebeck, 2002), 61-91.
}

56 Heinz-Martin Döpp, Die Deutung der Zerstörung Jerusalems und des zweiten Tempels im Jahre 70 in den ersten drei Jahrhunderten n. Chr. (Tübingen: Francke, 1998).

57 EP, LXXIII. 1: 'Introducitur populus Iudaeorum Deus supplicans, ut abuerteret ab Israeliticis quod imminebat exitium'; EP, LXXIII. 2: 'Intuere sollicite quot modis beneuolentiam Iudicis quaerat, ut oratorum argumenta hinc inuenias fuisse progressa'.

${ }^{58}$ For example, EP 73.9: ut debitas ultiones susceperint merito, in quibus nulla fuit tam multa crimina congrua paenitudo. 
Wars, to which Cassiodorus explicitly referred his readers, was a well-known literary model for the accounts of sieges, and only recently had the spoils of the temple been brought in triumph to New Rome by Justinian's general Belisarius after his victory over the Vandals. ${ }^{59}$ Cassiodorus himself, as we have already noted above, carefully molded the image of a Christian Rome onto the psalm's depiction of the fallen Jerusalem, thereby suggesting a connection between the biblical text and similar events in different cities. ${ }^{60}$

In Cassiodorus' treatment of the psalm, we can note a special interest in the historical role of the Romans as conquerors of Jerusalem and in their behaviour during the conquest. The resulting image was not particularly flattering. The Romans had come as wicked worshippers of idols to reduce Jerusalem and its temple to the ground, and 'the entire Hebrew people (gens Hebraeorum) either lay prostrate beneath the sword or were enslaved and reduced to captivity. ${ }^{61}$ It was therefore easy for Asaph to rouse God's anger against the Romans by meticulously describing the atrocities they had committed against the inhabitants of the city and against its sacred places. Cassiodorus carefully explained and amplified Asaph's description of the destruction and defilement of the temple, emphasising that this was the most heinous of all crimes. ${ }^{62} \mathrm{He}$ also noted that the Romans' lack of respect for the sacred sites cast a dire shadow on the fate of the city as a whole and its inhabitants: 'What then', he asked, 'could have happened to private dwellings, when the enemy's rage did not spare the Lord's sanctuary? ${ }^{363}$ Through their behaviour, the Romans showed that they had failed to understand the purpose of their military victory. They did not convert, but rather placed the statues of their own gods inside the temple: the Christian Rome evoked by Cassiodorus at the beginning of his commentary would be a reality only centuries later. ${ }^{64}$ Moreover, they succumbed to pride (superbia), the 'most cutting' - and most Roman - of vices. Setting up their army's flags and symbols, and erecting commemorative statues

\footnotetext{
59 Procopius, Wars, IV. ix. 5-10; see Michael McCormick, Eternal Victory. Triumphal Rulership in Late Antiquity, Byzantium, and the Early Medieval West (Cambridge: CUP, 1987), 14-17 and 64-68. In Wars, II. xii. 42, Procopius also reported a different version of the story of the temple treasure, namely that it had been seized by Alaric during the sack of Rome in 410.

${ }^{60}$ EP, LXXIII. 3.

${ }^{61}$ EP, LXXIII. 3 (translation slighlty modified).

${ }^{62}$ See EP, LXXIII. 4-7, for the detailed description of the events and violence done to both the temple and the remainder of the city.
}

${ }^{63}$ EP, LXXIII. 7. Cf. LXXIII. 1: 'Merito enim territus quaerebat [Asaph, GH] cur sanctuarium Domini passurum est nefandissimam uastitatem; timens ne, quia permissa est templi uastatio, iudaicus quoque populus funditus interiret'.

${ }^{64}$ EP, LXXIII. 4. 
over the triumphal arches and gates, they ascribed their success to their own merits rather than to God's will. ${ }^{65}$ To Cassiodorus, this was a tangible sign of the imperial victors' arrogance. ${ }^{66}$ Asaph therefore did well to return to the subject at the end of the speech, in order to 'rouse the allpowerful judge most emphatically against the foes of Jerusalem'. For, as Cassiodorus observed, 'pride is the vice which the Lord particularly abominates. [...] Notice how prudently this most cutting vice is set at the end; he intended to conclude with what should be stored in the confines of the memory'. ${ }^{67}$

Through his analysis of Asaph's rhetorical strategies, Cassiodorus made it very clear that the Romans of the psalms were a completely inappropriate example to imitate. At the same time, Asaph's plea served as a means to highlight certain topics which would have been especially relevant against the background of armed conflict in Italy. During the Gothic wars, the conduct of armies, the integrity of sacred places and the brutal treatment of the civilian population were certainly urgent problems, which were also discussed by other contemporary observers. ${ }^{68}$ Cassiodorus' critique of the first-century Romans, who had shown themselves to be cruel, disrespectful of God and unwilling to convert, may well have provoked reflection on the current situation in Italy; yet it is important to note that it is impossible to identify any specific group in the sixth-century wars with the biblical Romans and to associate Cassidorus' critique with either the imperial or the Gothic side.

Cassiodorus' exegetical strategy was thus designed to undercut the ideological potential of the psalm. Augustine, whose Enarrationes in psalmos he knew well and used extensively, had done the ${ }^{65}$ EP, LXXIII. 4 and 5-6. This was a stock argument about Roman arrogance, made in a similar way by Augustine, En.
in. ps., LXXIII. 8 .

${ }^{66}$ Cassiodorus specifically mentions the statues erected in praise of the emperors: EP, LXXIII. 4 and LXXIII. 5-6.

${ }^{67}$ EP, LXXIII. 23.

${ }^{68}$ See for example, the description of violence during sieges and the comments on brutality and lack of discipline of armies in Procopius, $W$ ars, ed. and trans. Henry B. Dewing, The Loeb Classical Library, 5 vols (Cambridge MA: Harvard University Press, 1954), v. ix. 22-30 and V. x. 27-33 (siege of Naples by Belisarius); VI. xxi. 39-42 (Milan) and VII. ix. 1-6. By contrast, he underlines the more civilised conquest of Carthage in Wars, III. xxi. 8-16; VI. xxix. 32-39 (Ravenna); VII. xx. 22-29. See also the descriptions of the siege of Naples and Rome in the Liber pontificalis, Vita Silverii, ed. Louis Duchesne, Le Liber pontificalis, 3 vols (Paris: E. de Boccard, 21955-57), I, pp. 290-95, cc. 3 and 5. The mistreatment of civilians by passing armies was also the topic of legislation issued by the emperor Justinian, as well as of political treatises: see the anonymous Dialogue on Political Science, trans. Peter N. Bell, in Three Political Voices from the Age of Justinian, Translated Texts for Historians, 52 (Liverpool: Liverpool University Press, 2009), 123-88 (p. 138 with n. 54); Codex Iustinianus, Nov. Cxxx, ed. Rudolf Schöll and Wilhelm Kroll, Corpus Iuris Civilis, 3 (Berlin: Weidmann 1894, repr. 1988). Cf. Walter Pohl, 'Perceptions of barbarian violence', in Harold Drake ed., Violence in Late Antiquity. Perceptions and Practices (Aldershot: Ashgate, 2006), 15-26. 
same in a sermon preached on the same psalm shortly after the sack of Rome in $410 .{ }^{69}$ Augustine had achieved this by downplaying the particular historical circumstances of the event, emphasising that the Romans were merely a small wheel in the machine of sacred history, and that under different circumstances, other reges gentium could have just as easily accomplished the task. ${ }^{70}$ Cassiodorus, by contrast, directed attention precisely at how the Romans had enacted their historical role as instruments of God's providence. ${ }^{71}$ He used Asaph's observations to criticise the historical agents of the psalm, and to draw attention to the impact of war and its moral repercussions. As we will see below, Asaph also became a vehicle for suggesting the right interpretation of and reaction to such events.

Similar observations can be made for Psalm 78. As a historical setting against which to read this psalm, Cassiodorus chose the Maccabean wars, when the Israelites fought against the Seleucid ruler Antiochus Epiphanes (175-134 BCE). ${ }^{72}$ Like the narrative of the fall of the second temple, the story of the Maccabees offered considerable potential for identification for Christian readers,

\footnotetext{
${ }^{69}$ Augustine, Enarrationes in Psalmos, [Enarr. in ps.], ed. Eligius Dekker and Jean Fraipont, 3 vols, CCSL 38-40 (Turnhout: Brepols, 1956), II, Enarr. in ps. LXXIII. For the dating to 411 or 412 see Michael Fiedrowicz and Hildegund Müller, 'Enarrationes in psalmos', in Augustinus-Lexikon II, 5-6, ed. Cornelius Maier (Basel: Schwabe, 2001), cols 804-48 (col. 819). On Augustine's reaction to the sack of Rome, see most recently Therese Fuhrer, 'Rom als Diskursort der Heterodoxie und Stadt der Apostel und Märtyrer: Zur Semantik von Augustins RombildKonstruktionen', in Henriette Harich-Schwarzbauer and Karla Pollmann eds, Der Fall Roms und seine Wiederauferstehungen in Antike und Mittelalter, Millennium-Studien, 40 (Berlin: DeGruyter, 2013), pp. 53-75; Richard Corradini, 'Die Ankunft der Zukunft. Babylon, Jerusalem und Rom als Modelle von Aneignung und Entfremdung bei Augustinus', in Walter Pohl and Gerda Heydemann eds, Strategies of Identification. Ethnicity and Religion in Early Medieval Europe, Cultural Encounters in Late Antiquity and the Middle Ages, 13 (Turnhout: Brepols, 2013), 65-142 (pp. 91-110), both with bibliography. On Augustine and sacred history, see the classic study by Robert Markus, Saeculum. History and Society in the Theology of St Augustine (Cambridge: CUP, 1970).

70 Augustine made a point of referring to the 'enemies' envoked in the psalm generically as reges gentium: Augustine, Enarr. in ps., LXXIII. 6. Only in Enarr. in ps., LXXIII. 8 do we find the adjective romanus; in Enarr. in ps., LXXIII. 3, where Augustine explains the connection between the death of Christ and the fall of Jerusalem, and the Romans appear via the citation of Io XI. 48. For the Romans as instruments in God's salvific plan, see e.g. Enarr. in ps., LXXIII. 8: 'facti sunt instrumentum irati, non in regnum placati'.
}

\footnotetext{
${ }^{71}$ Contrast, for example, EP, LXXIII. 4-7 with Augustine's treatment of verses 5-7, who declared that it was better to pass over these verses, since it is not appropriate to dwell on the punishment of the enemies (Augustine, En. in ps., LXXIII. 9).
}

${ }^{72}$ For background on this psalm, see Johannes Schnocks, "Gott, es kamen Völker in dein Erbe”: Psalm 79 [78] und seine Rezeption in 1 Makk', in Juda und Jerusalem in der Seleukidenzeit. Herrschaft - Widerstand - Identität, ed. Ulrich Dahmen (Göttingen: V\&R Unipress, 2010), 147-60. Other Latin exegetes (such as Arnobius the Younger or Hilarius of Poitiers) referred the psalm to the Philistine wars or the capture of Jerusalem under the Babylonian king Nebuchadnezzar II, or again to 70 CE. I have discussed aspects of Cassiodorus' exegesis of Psalm 78 in a previous article: 'Biblical Israel and the Christian gentes: Social metaphors and the language of identity in Cassiodorus's Expositio psalmorum', in Walter Pohl and Gerda Heydemann eds, Strategies of Identification. Ethnicity and Religion in Early Medieval Europe, Cultural Encounters in Late Antiquity and the Middle Ages, 13 (Turnhout: Brepols, 2013), 143-208, at $170-74$. 
not least with regard to its function as a prototype for Christian martyr narratives. ${ }^{73}$ Cassiodorus carefully spelt out for his readers the situation in which Asaph and the Israelites found themselves. A powerful city, once triumphant and a symbol of piety and orthodox belief, had been brought low by the imperialist ambitions of the Seleucid ruler, who exercised cruel domination alongside religious oppression. ${ }^{74}$

Despite his evocative description of the setting, Cassiodorus again refrained from drawing any straightforward analogies with political constellations of his own time - unlike, for example, Ambrose in fourth-century Milan, who had famously exploited this psalm to depict his Nicene community as a New Israel under threat from the empress Justina and the homoean Goths. ${ }^{75}$ And it is again by carefully following Asaph's movements as an orator that Cassiodorus established a critical distance towards both the beleaguered chosen people and its enemies.

As Cassiodorus made clear, Asaph's task in defending the people of Israel was not an easy one. After all, many Israelites had apostatised and abandoned the law, worshipping the foreign gods of their enemies and thereby calling into question their very status as the chosen people. ${ }^{76}$ Israel's affliction could thus be interpreted as a divine punishment for their aberrations. Under these circumstances, pleading 'not-guilty' was not an option for Asaph. He therefore began his speech (the dramatic beginning of the psalm - O God, the nations have come into thy inheritance) by formulating a judicial argument ad laesionem rei (an argument drawn from the thing harmed). This was meant to persuade God to rush to the aid of the Israelites by reminding him that they were, despite their shortcomings, his peculiar possession. ${ }^{77}$ When dealing with the guilt of the lapsed

\footnotetext{
${ }^{73}$ See the essays collected in Gabriela Signori ed., Dying for the Faith, Killing for the Faith. Old-Testament Faith-Warriors (1 and 2 Maccabees) in Historical Perspective (Leiden: Brill, 2010).
}

${ }^{74}$ EP, LXXVIII. 1; LXXVIII. 4: 'Gloriam illam Ierosolymorum toto orbe mirabilem usque ad opprobrium dicit uenisse uicinorum, ut quanta prius nobilitate resplenduit, tanta postea abominatione sorderet [...]. Contempti uero tunc sunt habiti, quando eos captiuitati traditos uidebant, quibus pridem tot regna cessisse cognouerant'. Cf. LXXVIII. 5, where Mathathias liberates the cinicus populus from the yoke of servitude and from the imposition of impious sacrifices.

75 Ambrose of Milan, Ep., LXXVI (20), ed. Michaela Zelzer, CSEL 82/3 (Vienna: Verlag der ÖAW, 1982), c. 20: 'Matutinis horis lectum est, ut meministis fratres, quod summo animi dolore respondemus: Deus, venerunt gentes in baereditatem tuam [Ps LXXVIII. 1). Et re vera venerunt gentes, et plus etiam quam gentes venerunt; venerunt enim Gothi, et diversarum nationum viri: venerunt cum armis, et circumfusi occupaverunt basilicam. Hoc nos ignari tuae altitudinis dolebamus, sed nostra imprudentia aliud opinabatur'. See the Engl. translation and commentary by Wolfgang Liebeschuetz and Carole Hill, Ambrose of Milan: Political Letters and Speeches, Translated Texts for Historians, 43 (Liverpool: Liverpool University Press, 2005), 124-36 and 160-73. For background, see Neil McLynn, Ambrose of Milan. Church and Court in a Christian Capital (Berkeley and Los Angeles: University of California Press, 1994), 181-96.

\footnotetext{
${ }^{76}$ EP, LXXVIII. 7.

${ }^{77}$ EP, LXXVIII. 1.
} 
Israelites, Asaph - as any respectable secular litigator would have done - deflected the attention of the divine judge away from the inexcusable crimes of his clients, by reminding Him of the even greater shortcomings of their enemies, who were wholesale pagans. ${ }^{78}$ Another strategy employed by Asaph was to use the prestige of the patriarch Joseph to mitigate God's anger towards the people: 'he put forward the name of the most acceptable patriarch to represent the sinning people (gens), so that the recollection of that most holy man could lessen the sins of the people. ${ }^{79}$ But in the end, Asaph's most efficient strategy of defence was to resort to the argument of concessio, that is, the simple confession of one's fault and bid for forgiveness. ${ }^{80}$ Asaph's clients, the Israelites, were at times dissatisfied with God's dispensation, unwilling to acknowledge his justice. Their advocate, by contrast, put his trust in God. Moreover, he slowly came to develop a more conciliatory perspective. Rather than merely evoking divine wrath against Israel's enemies, he actually prayed for their conversion - that is, at least in the reading of Cassiodorus, who reinterpreted Asaph's fervent call for revenge in this sense. ${ }^{81}$

By concentrating on Asaph's rhetorical performance, Cassiodorus substituted Asaph for Israel as a model of identification. In the course of his speech in front of the divine judge, Asaph was transformed almost imperceptibly from a vigorous litigator into an exemplary Christian orator. Earlier in the text, Cassiodorus had contrasted Asaph's skill with that of secular orators, discerning in it the efficacious use of the rhetorical figure of climax (auxesis). Where are the orators who have adapted such service of the truth to the art of verisimilitude (Vbi sunt oratores qui ad artem uerisimilem ueritatis officia transtulerunt)', he asked, adding: 'Observe the arguments wielded by talented simplicity rather than malicious craftiness'. ${ }^{82}$ Clearly, secular orators had deflected the

\footnotetext{
${ }^{78}$ EP, LXXVIII. 6. Cassiodorus makes it very clear that this was Asaph's strategy to arouse God's indignation against the enemies: 'He says: Pour out thy wrath, meaning, "discharge your indignation in abundance over your enemy, so that they may be overwhelmed by Your powers as they now oppress us". He realised that men's triumph can last only so long as the divine power permits. And when he says: That have not known thee, he is palliating the faults of the Jews; for though many of them had sinned, there were none the less those among them who attended to the Lord's commands. He says that those wholly ignorant of the Lord's name are rightly to be attacked, and thus their own inexcusable guilt is lightened by comparison with the greater sin'.

79 EP, LXXVIII. 7: 'pro gente quae peccauerat, gratissimae patriarchae nomen obiectum est'. Cf. for a similar interpretation EP, LXXIII. 21.
}

80 EP, LXXVIII. 8: 'Confessione delictorum propitium sibi iudicem reddit, ut qui se per iustitiam uindicare non poterat, per supplicationes necessarias expiaret'; LXXVIII. 10: Qui de propriis uiribus desperat, necessarie ad auxilium omnipotentis iudicis currit, ut quod actibus propriis conferri non potest, pietate sancti nominis trinuatur'. On concessio, see below, n. \$(85).

${ }^{81}$ See below, pp. \$.

${ }^{82}$ EP, LXXVIII. 4. 
art of truth from its biblical origins, and thereby compromised it. ${ }^{83}$ How, thus, should it be used? While, as we have seen, Asaph himself at times needed to bend the truth to advance his clients' cause, he ultimately abandoned such doubtful strategies in favour of confessing the sins of his people and asking for forgiveness, thereby conveying to his audience a message about how to react in the face of violent conflict and oppression, namely with perseverance and trust in God.

Elsewhere, Cassiodorus interrupted his exegesis of another 'judicial psalm' (Psalm 31) with an appeal to secular orators, urging them to take the penitent prophet's speech as their model and to enhance the credibility and moral integrity of secular legal practice ${ }^{84}$ In contrast to secular judicial oratory, where litigators sometimes used their abilities to defend a false truth, and judgements could be ambigous or even corrupt and purchased by money, its biblical counterpart was characterised by an uncompromising commitment to veracity and justice. Here, facts counted more than words (causa plus clamat quam lingua); the technique of concessio (which was also used by Asaph in his plea on behalf of the Israelites), although considered to be the last resort of the laywer in traditional rhetorical handbooks, became the centerpiece of the orator's strategy. ${ }^{85}$

Cassiodorus carefully weighed against each other the two types of oratory with which he was familiar. Although he acknowledged (and emphasised) the difference between them, he also articulated the hope that they might draw closer. It is worth remembering that topics such as the moral excellence (and rhetorical skill) of advocates or the integrity of judges and the legal system were also important issues in in Ostrogothic Italy, as evidenced in the Variae and the Edictum Theoderici. ${ }^{86}$ In the context of Justinian's projects of legal reform and codification, the Christian dimensions of imperial law and authority received renewed emphasis, and legal practice and

\footnotetext{
${ }^{83}$ On the notion of biblical eloquence as characterised by greater truthfulness and purity, see Astell, 'Cassiodorus' commentary', 59-61; Agosto, 'Su Cassiodoro', 296-98; Weissengruber, 'L'educazione profana', 64-69. On the classical problem of the veri simile in patristic thought: Hans Blumenberg, 'Kritik und Rezeption antiker Philosphie in der Patristik. Strukturanalysen zu einer Morphologie der Tradition', Studium Generale, 12 (1959), 486-97; Tornau, Zwischen Rhetorik und Philosophie, 20-35.

${ }^{84} E P$, xxxi.7: 'Venite, oratores, qui negotia humana artificiosa subtilitate tractatis; uidete reum se lacrimis diluentem, audite peccatorem confessionibus absolutum, intellegite sententiam principis non salutem hominis impetere, sed potius peccata damnare. Ista sunt tribunalia, quae nullus redimit, ista sententia quae nihil sub ambiguitate decernit. Tali potius modo causas uestras defendite, qui negando ueritatem cum criminibus consuestis delicta uestra miscere. Conuertite ordinem saecularium iudiciorum, orationem uestram ab epilogis incipite, peruersas flebiliter narrate miserias, correctionem protinus ueraciter intimate, et tunc meremini gaudentes concludere quod flentes feliciter incohastis'. Cf. Astell, 'Cassiodorus' commentary', 59-61.
}

${ }^{85}$ EP, xxxI. 5. On Cassiodorus' use of concessio, see Astell, 'Cassiodorus' commentary', 52-62, who at 54 points to the contrast with Cicero in De inventione, where he advised his readers to avoid concessio and deprecatio in court (Cicero, De inventione, ed. Eduard Stroebel [Leipzig, 1915, repr. XXX1977], II. xxxiv. 104).

86 See the references in Sean Lafferty, 'Law and order in the age of Theoderic the Great (c. 493-526)', Early Medieval Europe, 20 (2012), 260-90, at 275 and 285-86. 
education became the subject of political debates. The imperial quaestor Junillus Africanus composed an exegetical treatise in the 540s with the significant title Instituta regularia divinae legis, in which he discussed the Christian foundations of human law and governance; Cassiodorus knew the work and recommended it in his own Institutiones. ${ }^{87}$ Against this background, Cassiodorus' presentation of Asaph as an ideal orator seems particularly interesting.

In Cassiodorus' exegesis of both Psalm 78 and 73, Asaph took centre-stage as a model for orientating Cassiodorus' Christian audience in a more general sense too. In his concluding remarks, Cassiodorus exhorted his readers to let themselves be persuaded by Asaph's speech, and to adopt a similar attitude towards the fate of their own community: 'We must also ponder and store deep in our minds that we are being advised to rejoice with zealous charity at the blessings on God's church, and to feel sore grief at her disasters'. Citing Paul's letter to the Corinthians (I Cor xii. 26), Cassiodorus reminded them that love of one's neighbour and compassion were essential to the social cohesion of a Christian society. ${ }^{88}$ Asaph's forensic speech contributed to the definition of an ideal community characterised by caritas and unanimity. Likewise, the most remarkable aspect of Psalm 73, although Asaph ended his speech with a note of rebuke against the Romans, remained his prayer for mercy and conversion on behalf of those members of his own community who were still refusing to believe in Christ. ${ }^{89}$ Cassiodorus specifically alerted his audience, the auditores egregii, to the compassionate way in which Asaph cared about the fortune of his community:

Worthy listeners, you have understood how sweet are the duties of piety (officia pietatis) to those most faithful men (fidelissimi uir): you have heard how they are unwilling that their descendants should bear the melancholy, and therefore lament with countless tears the latters' future calamities. This indeed is the holy perfection of charity (caritas), to bring to mind the future dangers which one fears will descend on one's successors. ${ }^{90}$

\footnotetext{
${ }^{87}$ Caroline Humfress, Orthodoxy and the Courts in Late Antiquity (Oxford: OUP, 2007), 196-215; Michael Maas, 'Roman history and Christian ideology in Justinianic reform legislation', Dumbarton Oaks Papers, 40 (1986), 17-31; idem, Exegesis and Empire in the Early Byzantine Mediterranean. Junillus Africanus and the 'Instituta regularia divinae legis' (Tübingen: Mohr Siebeck, 2003), esp. 12-13, 67-75; Tony Honoré, Tribonian (Ithaca: Cornell University Press, 1979), pp. 1-39. Cassiodorus cites Junillus in Institutiones, I.x.1.

88 EP, LXXVIII. concl.: 'Considerandum quoque et alta mente condendum est quod caritatis studio commonemur Ecclesiae Dei bonis laetari et iterum calamitatibus eius uehementer affligi. [...] Quapropter conuenit ut quod unicuique fidelium prouenerit, ad nostros dolores proximitatis studio transferamus, sicut apostolus dicit: Si quid patitur in unum membrum, compatiuntur omnia membra, siue gloridicatur unum membrum, congaudent omnia membra (I Cor xii. 26)'.

${ }^{89}$ EP, LXXIII.20 and 22.

${ }^{90}$ EP, LXXIII. concl.: 'Cognouistis, auditores egregii, quam suauia sint fidelissimis uiris officia pietatis: quemadmodum nolint proxmios suos tristitiam sustinere, ut de futuris cladibus tantis lacrimis affligantur. Haec est reuera caritatis sancta perfectio praesentare futura sibi pericula, quae proximis formidantur esse uentura'. (Trans. slightly modified).
} 
Asaph thus turned into a vehicle for the right interpretation and evaluation of the story told in the psalms, and at the same time served as a voice for Cassiodorus' own comments and concerns. For Cassiodorus, then, what seems to have made these psalms especially interesting was their potential to provide a language with which to address and interpret comparable events in his own day.

The potential for identification with the biblical orator becomes particularly apparent with regard to Psalm 72, where the voice of the psalmist is very strongly present in the biblical text. For this psalm, Cassiodorus did not offer any specific chronological setting, but concentrated entirely on the efforts of Asaph, who struggles to find a valid perspective on the evils endured by his community. The Israelites watch their enemies prevail and lead prosperous lives instead of receiving the deserved punishment for their sins, while they themselves are exposed to affliction and poverty despite their best efforts to live righteously. Asaph is therefore confronted with questions about the religious significance of success or calamity, and about the right reaction to such events. Does God take any interest in the fate of his chosen people, and what difference does it make whether or not we try to lead a righteous life? Can defeat or victory in battle, or prosperity and achievements in this world, be interpreted as signs of God's benevolence towards a community? Following Augustine, from whose vivid sermon he derived much of his material, Cassiodorus identified as the major issue in the psalm the question of divine justice and intervention in human affairs. ${ }^{91}$

Cassiodorus closely observed the process through which Asaph slowly reached the right understanding of such issues. In the beginning, Asaph himself was haunted by doubt. Much like the Israelites, he felt envy towards the worldly achievements of the sinners, and confessed that he 'had almost fallen when the Lord's dispensation irrationally displeased him'. ${ }^{92}$ In Asaph's case, the crisis of confidence in God's justice and the reliability of divine power was especially serious because of his responsibility as a leader of the Israelite people. ${ }^{93}$ But slowly, Asaph stepped up to

\footnotetext{
${ }^{91}$ See, in particular, Augustine's concise summary of the issues at stake in the introduction to his sermon: Enarr. in ps., LXXII. 5-6.

${ }^{2}$ EP, LXXII. 2: 'ut paene lapsum se diceret, cui administratio domini irrationabiliter displicebat'; see also LXXII. 3 and $13-14$.

${ }^{93}$ See the comments in EP, LXXII. 15 (on the verse 'If I say, "I will speak thus," behold, I should offend against the generation of Thy children'), where Cassiodorus analyses Asaph's reflections on what to teach the Israelites.
} 
his task to offer moral guidance to his community. In an attempt to explain to them the right reaction to suffering and injustice in this world, he urged them to consider eternal salvation rather than temporary happiness. The faithful should not let themselves be deceived by the prosperity of sinners - even if it might seem otherwise at times, God is neither unjust nor indifferent towards the fate of his people. Not only will sinners receive their just punishment in due course, it is also wrong to hope for tangible rewards rather than spiritual goods in return for faith and pious works. ${ }^{94}$

Cassiodorus could thus conclude that Asaph's knowledge of the divine law, along with his rhetorical abilities, had enabled him to regain his good judgement. ${ }^{95}$ In his exegesis, Cassiodorus not only (like Augustine before him) clarified Asaph's reflections for his own audience. In addition, he explicitly likened Asaph's intellectual efforts to that of an orator: 'This kind of speech is termed "deliberative", when arguments are propounded which make us uncertain, and the judgement is selected which is appropriate to what is both advantageous and honorable'.96 The rhetorical handbooks defined the genus deliberatiuum as an advisory speech, most often delivered in front of a political audience, and dealing with matters of public interest and policy. According to Cicero and Quintilian, the goal of a deliberative speech was to reach political decisions by taking into account both the expected outcome of an action (utilitas) as well as its compatibility with the socially accepted norms and values (the honestum or decorum). ${ }^{97}$ Ambiguity and contention arose where the useful and the honorable, the two principles for good decisionmaking, conflicted with each other, or where the issue at stake was itself morally ambivalent. Cassiodorus noted that Asaph's problem consisted precisely in such a causa anceps, 'as it is common in deliberative speeches, when the mind is uncertain about the outcome. ${ }^{98}$

\footnotetext{
${ }^{94}$ For these messages (sometimes clarified by Cassiodorus), see EP, LXXII. 18-20 (punishment for sinners); LXXII. 25 (spiritual rather than earthly hope) and LXXII. 15 (God's care and justice).

${ }^{95}$ EP, LXXII. 17 (the lex dinina as a guide to knowledge); LXXII. 14 (Christ and his gospel).

${ }^{96}$ EP, LXXII. 17: 'Quod genus orationis dicitur deliberatiuum, quando et partes ponuntur, quae nos dubios redunt et eligitur sententia, quae et utilitati conueniat et decori’.
}

97 See Cicero, De inventione, I. v. 7 and II. lii. 157-58 on utilitas and honestas as criteria in a deliberative speech; cf. Quintilian, Instituta oratoria, ed. Michael Winterbottom, Oxford Classical Texts, 2 vols (Oxford, OUP, 1970 ), III. 8. On the classical background for deliberative speech, see Kennedy, Art of Rhetoric, 18-21; Fantham, The Roman World, 209-36; Michael C. Alexander, 'Oratory, rhetoric, and politics in the republic', in William Dominik and Jon Hall eds, A Companion to Roman Rhetoric, (Malden MA and Oxford: Blackwell, 2007), 99-108.

${ }^{98}$ EP, LXXII. 13: Hoc genus causae ab oratoribus anceps dicitur, quod maxime in deliberationibus praeuenit, quando dubius est animus quid sequatur'. Cicero described the causa anceps as a case where honourable and shameful aspects (honestas, turpido) were intermingled (Cicero, De inventione, I. xv. 20: 'anceps, in quo aut iudicatio dubia est aut causa et honestatis et turpitudinis particeps, ut et benivolentiam pariat et offensionem'). Cassiodorus proceeds to give a 
Aptly, Cassiodorus framed the tension between secular aspirations and spiritual goals discussed in the psalm not least as a political problem: The sinners 'are seen to be wealthy, to dominate many peoples, to have no fears in this world, and are thought to possess peace'. ${ }^{99}$ He also clothed the psalmist's critique of the arrogance of sinners, who think that their blasphemous thoughts and deeds will remain unpunished, in political language, attributing their actions to a tyrannica noluntas which led them to overstep human boundaries in the erroneous belief that they could act with impunity. ${ }^{100}$ To convey to his readers a sense of the depth of the veritable crisis of identity which Asaph and his community confronted, Cassiodorus compared the loss of adequate patterns of interpretation with the experience of alienation from one's homeland, the loca patriotica, a situation with which he was himself familiar. ${ }^{101}$ At stake was no less than the collective fate of the community and its relationship to a logic of divine retribution.

As Ann Astell has observed, the concept of deliberative speech shifted towards a distinctly spiritual understanding as Cassiodorus applied it to the psalms, taking on connotations of inner debate and personal meditation; yet it also retained its political meaning. ${ }^{102}$ After all, Asaph spoke as the representative of the people of Israel, and his problem consisted in discerning what kind of message to convey to this populus. When classical orators weighed the expected political or material benefit (utilitas) of an action against its moral quality, the honestum, they were in a sense negotiating the moral order of their society. ${ }^{103}$ This is not dissimilar to what biblical orators like

definition of causa, which links it to the notion of contingency by means of a playful etymology: 'Causa enim a casu dicta est, quod saepe bona sit, saepe mala'. He was however familiar with Cicero’s definition of causa, which he cited in Institutiones, II. ii. 8.

99 EP, LXXII. 3: Nam cum peccatores uidentur locupletes, multisque dominari populis et in mundo non esse quod timeant, putantur habere pacem [...]'. See also LXXII. 20, where Cassiodorus takes up Augustine's warning that dreams of wealth, honour, marriage or a position of power (imperium desideratum) will turn out empty and vain.

100 EP, LXXII. 9. Cassiodorus warned such people not to think that their secular honours (dignitates) would outlast their human lives.

101 EP, LXXII. 10.

102 The spiritualisation is especially clear in Psalm 76, another speech by Asaph, where Cassiodorus defined the genus deliberatiuum in terms of an inner debate which did not concern itself with obtaining temporal benefits: EP, LXXVI. 7 ('Proprie actus ipse deliberationis exprimitur. Exercemur enim, quando per retractationes innumeras aestuamus et quasi in palestra animae spiritali concertatione fatigamur'); cf. LXXVI. 1. For an elaborate discussion, see Astell, 'Cassiodorus' commentary', 43-53.

103 Cicero defined the honestum as the sum total of things we desire for their own sake, see De inventione, II. liii. 159. Note that he devoted part of his treatment of the genus deliberativum to a discussion of the four political virtues: Cicero, De inventione, II. liii. 160-65. Cf. Cicero, De oratore, ed. Augustus S. Wilkins, Oxford Classical Texts (Oxford: OUP 1902, repr. 1963), II. 333-340. 
Asaph (or Cassiodorus) were doing for their respective communites. It is easy to see the social relevance of questions about divine retribution for sin and the corollary of human behaviour. The same is true for reflections about God's intervention in this world and the reasons for it, or about the tension between human responsibility and divine providence. Asaph's speech (like Cassiodorus' exegesis) was concerned with the ethical foundation of action in a (Christian) society.

Reassuringly, as Cassiodorus pointed out, the outcome of Asaph's deliberation was that 'the judgement was selected which is appropriate to both the useful and the honorable'. ${ }^{104}$ Rhetoric thus allowed for the different principles of decision-making to converge, and offered a way to reconsider the underlying norms and values which were to serve as a frame of interpretation from a Christian perspective. This stands in sharp contrast to the wicked rhetoric of sinful people, whose way of speaking Cassiodorus characterised as a 'ratiocinatio sine ratione, tractatus sine consilium, cogitatio sine sapore (reasoning without reason, discussions without consultation, thoughts without savour)', that is, as a kind of anti-rhetoric. ${ }^{105}$ Cassiodorus ended his commentary by praising Asaph's performance, which commanded all the more authority because it was grounded in scripture. ${ }^{106}$

Asaph's role as a political leader is here defined by his interpretative authority; the practice of leadership is closely tied to rhetorical practice. Cassiodorus, then, read Psalm 72 not only as a reflection on the moral standing of a community and on the religious significance of historical events; it was also an important lesson on how a political leader and teacher like Asaph should explain such issues to his community. As will be discussed in more detail below, Cassiodorus in a sense carried further this practice of deliberation for his own audience in his commentary, clarifying and reinforcing the lessons taught by Asaph, and incorporating a strong affirmation of Chalcedonian orthodoxy into his text. ${ }^{107}$ As in Psalm 73 and 78, Cassiodorus ended his commentary on Psalm 72 with an emphatic conclusion, in which he sought to persuade them to adopt the moral perspective and theological lessons developed from the psalm: 'Grant O Lord,

\footnotetext{
${ }^{104}$ EP, LXXII. 17: 'eligitur sententiae quae et utilitati conueniat et decori'.

105 EP, LXXII. 12.
}

106 EP, LXXII. concl: 'Deliberauit enim sapienter, elegit eximie [...] quando utrasque cogitationum partes, uelut iusta libra discernens, aequabili totum moderatione pensauit. Completa est his admonitionibus institutio Christiani, ut nec cogitationibus prauis delinquat, qui se Domino commendare festinat'.

107 EP, LXXII. 24-25. Cf. below. 
that you do not make us envy the men whom you condemn by your truth; but let us curse those whom you abhor, and be fond of those whom you love; for only those who follow your wishes with a most devoted heart can have their portion with you'. ${ }^{108}$ Cassiodorus thus assumed Asaph's position as a teacher with regard to his own audience. Through the work of the exegete, the psalm became a vehicle for the 'formation of the Christian' (institutio Christiani). Like Asaph's speech, Cassiodorus' exegesis was designed to develop patterns of interpretation and guidelines for action and reaction for a Christian community.

\section{The exegete as orator}

As an exegete, Cassiodorus continued Asaph's work as an orator. Through his appropriation of the voice of the psalmist, we can trace his response to events and problems treated in the psalms which were also the subject of debate in the sixth century. As we have seen, he was much concerned with the religious significance of military events and the behaviour of conquering armies. ${ }^{109}$ An important lesson to be derived from the story about the Maccabean wars as told by Asaph, for example, was that divine approval and support in times of affliction were conditional upon upholding orthodoxy and the correct observance of the cult. ${ }^{110}$ Only the part of Israel who had, under Mathathias' leadership, remained steadfast in their faith and upheld the law despite potential repercussions, were truly to be considered 'God's people', as Cassiodorus explained to his readers. ${ }^{111}$ Asaph's speech was also a reminder of the solidarity and charity necessary for the internal cohesion of such a community. ${ }^{112}$ Conversely, Cassiodorus elsewhere identified religious dissent among the Israelites (described as a certamen nefarium) as the root of all further misfortune which befell them. ${ }^{113}$

108 EP, LXXII. concl.: 'Praesta, Domine, ne nos talibus inuidere facias, quos tua ueritate condemnas, sed exsecremur quos horres, et amemus certe quos diligis; quia tecum nequeunt habere portionem, nisi qui uoluntates tuas mente deuotissima subsequuntur'.

109 See above, pp. \$.

110 EP, LXXVIII. 5 and 9, where the leadership of Mathathias is presented as divinely sent aid for the Israelites, which also helped to purge them of their idolatry. Contrast Augustine, Enarr. in ps., LXXVIII. 12: 'nam quid aliud mererentur peccata nostra, quam debita et digna supplicia'.

${ }^{111}$ EP, LXXVIII. 13 on 'But we, thy people and the sheep of thy flock, will confess thee forever': 'In my opinion, he is speaking of the remnants gathered together by the enthusiasm of Mathathias, whose merits enabled them to maintain the law of the Lord. They are truly the Lord's sheep, for they proclaimed His glory and remained steadfast in faith'. The righteous part of Israel is then equated with the Christian populus.

112 EP, LXXVIII. concl. Cf. above, n. 84.

113 As he observed in EP, LXXIx. 7, another psalm of Asaph lamenting the destruction of Jerusalem. 
The logic of human sin and divine retribution seems to have been of particular concern to Cassiodorus, especially in its relation to the collective fate of a community. The rhetorical construction of the Asaph-psalms in itself presupposed to a certain extent the idea of redistributive justice, since it was based upon the assumption that Israel's destiny (much as that of other peoples) lay in God's hand (and that the impending destruction of the people could be averted through the art of persuasion). ${ }^{114}$ In the commentary on Psalm 72, Cassiodorus discouraged the opinion that tribulation on earth is always a sign of divine anger; sometimes, it is intended as an incitement to correction. ${ }^{115}$ Yet he unmistakably affirmed that the world is governed by God's sovereign will. Human actions indeed have moral consequences, and human history unfolds not through mere chance, but is subject to divine providence, which we must respect and follow. ${ }^{116}$ And although Cassiodorus acknowledged that the faithful should focus on spiritual rather than temporal rewards for their behaviour, while sinners would receive the just punishment at the final judgement, he still sought to preserve some sense of retribution already in this world. ${ }^{117}$

114 See, for example EP, LXXIII. 8-9 and LXXIII. 18; cf. Moses' role as an intercessor in EP, LXXXIX and EP, CV. 23. On the notion of redistributive justice in early Christian historiography, see Garry W. Trompf, 'Rufinus and the logic of retribution in post-Eusebian church histories', The Journal of Ecclesiastical History, 43 (1992), 351-71.

115 EP, LXXII. 15; cf. LXXII. 5: 'tribulatio siquidem istius saeculi fidelibus uotiua correctio est'. Cassiodorus also developed this theme through the analysis of other biblical speeches delivered by Asaph (EP, LXXX. 14-15) or Moses in Psalm 89 (EP, LXXXIX. 15: 'Tribulationes quas hominibus prouidentia diuina concedit, quam ueraci aestimatione perpenderat, ut delectatum se in eis diceret, per quas humilandum populum salutariter sentiebat'; cf. LXXXIX. 9 and 11). Augustine likewise dwelt on the issue at length with regard to Psalm 89: Enarr. in ps., LXXXIX.11 and 13.

116 EP, LXXII. 15: 'Dicebat enim: Si annuntiauero plebi Deum mortalia non curare, occurere sibi putat praedicationes priores, quas Israelitis ante praedixerat, ut Deum colerent, caeli terraeque Creatorem, qui per suam sapientiam uniuersa disponit, bonis malisque pro suorum actuum qualitate restituens'. Augustine, by comparison, stressed that God's justice remains unscrutinable and his judgement difficult to discern behind the events of this world, after having reprimanded those who believe in astrology: Augustine, Enarr. in Ps., LXXII. 22: 'Vere magnus labor, cognoscere quomodo Deus curet res humanas, et bene sit malis, et laborent boni! Magna uim quaestionis!'. As Cassiodorus stated with regard to another of Asaph's speeches, he was an example for the 'truly wise men' (ueri sapientes), who put their trust in God's potestas and ordinatio, EP, LXXVI. 2: 'Quapropter uere sapientes sunt, qui se potestati diuinitatis ordinationique committunt'; LXXVI. 4: 'qua sapientia cuncta disponat, quali potentia uniuersa contineat'.

117 EP, LXXII. 18. While Cassiodorus generally followed Augustine in underlining the importance of spiritual rather than temporal rewards, at this point he remarked that sinners, even when prosperous and successful, could never escape the consequences of their inner guilt, and that moreover, 'even in this world, such people often incur the destruction which they do not even suspect'. Cf. EP, LXXx. 14-15, where he likewise asserted that God 'opposes our enemies when we dedicate ourselves to Him with humble satisfaction. If we oppose God by evil action, He in turn refrains from refuting our enemies, and He does not lay a protecting hand on those who have drawn away from him with proud struggles'. 
The Psalter contained many terrifying examples of divine punishment and the political consequences of religious error. Cassiodorus was clearly haunted by such questions, and he kept reframing his answers - perhaps understandably so, given his past commitment to a heterodox regime which was on the verge of collapse. He was also attentive to the tension between collective guilt and individual responsibility raised by such instances of divine punishment. ${ }^{118}$ But the psalms also offered some reassurance concerning the possibility for men to influence or reverse their fate by repenting and taking appropriate action. In Psalm 142, one of the penitential psalms, King David, troubled by the assaults of his son Absalom, laments his past behaviour and prays for forgiveness of his sins. Cassiodorus took this as an occasion to remind his audience of the efficacy of prayer and penance on both an individual and a collective level. While David's penitential prayer functioned as an example of each level for the orator sanctissimus, Cassiodorus also urged his readers to consider the story of the city of Niniveh, when the whole population had grieved and fasted and thus succeeded in escaping the impending disaster foretold by the prophet Jonah. ${ }^{119}$ Similarly, if there was any comfort to be derived from the narrative of Jerusalem's fate in $70 \mathrm{CE}$, it was that even the Israelites could have prevented the destruction of the temple, if only they had repented in time and confessed their guilt (as Asaph, the orator, had suggested). ${ }^{120}$

Another result of Cassiodorus' exegesis of the rhetorical psalms was to convey to his audience a distinctly spiritual perspective on how to react in times of violent conflict and how to deal with potential enemies. This was a model which emphasized the possibility of reconciliation and conversion rather than violent subjugation or destruction. As already briefly noted above, Cassiodorus reinterpreted Asaph's frequent calls for divine revenge against Israel's enemies as pleas for their conversion. Thus, when Asaph called upon God to 'avenge the blood of thy servants which has been shed' (Ps lxxviii. 10), he did not speak of temporal vengeance as 'the means by which force and injustice are repelled by just retribution'. Rather, by interceding with God on behalf of Israel's enemies, Asaph exhibited the proper Christian attitude according to the precept of the gospel, which Cassiodorus proceeded to cite: 'pray for your enemies, do good to

\footnotetext{
118 See, for example, his discussion of the Israelite defeat against the Philistines after they had captured the Ark of the Covenant, in EP, LXXVII. 62, where Cassiodorus assured his audience that despite the subjugation of the people, those Israelites who were of upright conscience nevertheless enjoyed God's protection.

119 EP, CXLII. concl.: 'Sed cum isti singillatim delicta nostra nos deflere commoneant [...], exstat tamen et illud Niniuitarum efficacissimum supplicationis exemplum, ubi cunta aetas ingemuit, ubi sensit pecus omne ieiunium; et tantum ualuit afflictio generalis, ut ueritatem potuisset prophetici superare sermonis'.
}

120 EP, LXXIII.18: 'Sic pro cupabilibus rogat, ut eorum semper confiteatur errata. Hoc si Iudaei fecissent mente deuota, potuerant generaliter debita uitare supplicia'. 
those who hate you (Mt v. 44)'. ${ }^{121}$ Similarly, when Asaph called upon God to intervene against the Romans in Psalm 73, he did not, according to Cassiodorus, hope for a military counterstrike, but rather prayed for their eventual conversion. ${ }^{122}$ While this was by no means an unusual way to deal with the violent language contained in the psalms and other books of the Old Testament, this message seems to have been of particularly urgent concern to Cassiodorus. He frequently returned to this theme throughout the commentary, and he sometimes invested considerable exegetical effort in arriving at this conclusion. ${ }^{123}$

Moreover, Cassiodorus explicitly advocated it as a rule of conduct for a Christian people. This is the case in Psalm 137, where he identified as the speaker of the psalm the populus catholicus who praised God and prayed for the conversion of kings (reges terrae) and even of enemies. The psalm was an exemplary oratio ('perfecta nimis et qualem fundere monemur oratio') not only because the unity and consensus among this people was so profound that they could be said to speak with one voice (una nox). More importantly, they spoke not with anger, but appealed to God's mercy for the repentance and salvation of the sinners. ${ }^{124}$ At the end of his commentary, Cassiodorus therefore again directly exhorted his readers to imitate the speakers of the psalm:

Let us pay heed to the nature of this proclamation by which the holy people (sanctus populus) has instructed us [...]. They sought to cut out all their hearts' resentment (zelum cordis) against their enemies, so they asked that those who seemed to be hostile towards them

121 EP, LXXVIII. 10: 'Vindicatio est enim per quam uis et iniuria iusta retributione defenditur. Sed hic illud uidetur optari, quod ad conuersionem respicit inimici. Nam cum hic in eis temporaliter uindicatur, interitum aeternae damnationis euadunt [...]'. Cf. also LXXVIII. 12. Cassiodorus based his reading of these verses on Augustine, who likewise claims that the intention of the speakers (according to him, Christian martyrs) is to pray for the well-being of their enemies. But there is an interesting difference in that Augustine preserved a sense of the martyrs' wish for retribution, explaining it by their (rightful) zeal for justice; this notion is absent from Cassiodorus' text, who instead reinterprets the verse entirely in terms of conversion and love for one's enemies. See Augustine, Enarr. in ps. LXXVIII. 9,14 and 16.

\section{EP, LXXIII. 3.}

${ }^{123}$ For a particularly telling example, see EP, XLIII. 6, where Cassiodorus disarmed the psalm's vehement call for the destruction of the enemies not only by referring this violent conflict to the struggles of Christian martyrs rather than Christian armies, but also by reminding his readers of the Augustinian notion that there existed a fundamental difference between the Old and the New Testament with regard to God's physical intervention on behalf of his people. See below, n. \$ (n. 137).

${ }^{124}$ EP, CXXXVII. 8 (on 'Domine, retribues pro me, misericordia tua in aeternum'): 'Perfecta nimis et qualem fundere monemur oratio est, causam suam Domino commendare, qui nouit unicuique digna rependere. Sed ut hoc non iracunde dictum, quod deprecationi uidetur esse contrarium, potuisses accipere, sequitur in misericordia tua aeternum', quam facias et illis qui nos persequuntur immaniter; ut sicut nos pro tuo nomine uidentur affligere, ita et illi confessionis munere cruciari debeant ad salutem'. The context for this verse is the reinterpretation, in the commentary, of the conflict scenario in the psalm text as a battle between Christian martyrs and persecutors. 
should become their associates (socii). Let us imitate their devout sentence and opt to love those who afflict us. ${ }^{125}$

To this, Cassiodorus added that we should perceive enemies not simply negatively and as hostile to us, but positively, since dealing with them could actually provide an opportunity to exercise patience and thus be more useful than always being surrounded by the amicable presence of friends. ${ }^{126}$ This was certainly good advice for every Christian, but it may have been especially relevant to members of the Italian elite as they were dealing with the hostilities between different groups during the Gothic wars. ${ }^{127}$

That Cassiodorus would have responded to such issues with particular sensitivity is certainly understandable given the political background against which he was writing. His reflections on the Christian attitude towards enmity and war, on the tension between collective and individual responsibility and between human agency and the providential sequence of history could indeed have contributed to a broader societal debate. ${ }^{128}$ Old Testament language and models played an important role in the historiographical debates which accompanied Justinian's wars against Ostrogothic Italy and Vandal Africa. In Justinianic legislation, the emperor's actions were presented as expressions of God's will, and imperial success as the result of divine favour. ${ }^{129}$ There is a substantial amount of biblical precedent and providential rhetoric in the works of the poet Corippus, who presented the Vandal expedition as the triumphant realisation of a divinely inspired plan. ${ }^{130} \mathrm{He}$ used biblical imagery to argue that the Roman victories were a sign of God's

125 EP, cXXXVII. concl.: 'Intendamus quali nos praedicatione populus sanctus imbuerit, quanto instinctu pietatis orauerit. Nam ut omnem nobis contra inimicos zelum cordis excluderet, ipsos rogauit sibi fieri socios, quos habere uidebatur aduersos. Sequamur sententiam piam, amemus potius affligentes. Non debemus inimicos aestimare qui prosunt; nam si aequo animo perferantur, frequenter nobis talia conferunt, qualia dulcissimi amici praestare non possunt. Isti enim saepe nos a uirtute blandiendo deducunt; illi uero in eadem affligendo constituunt. Quapropter ama patientiam et plus inuenis in inimico quod diligas'.

126 EP, cXXXVII. concl.

${ }^{127}$ In this context, we may note that the populus also specifically exhorted kings (reges terrae) to righteous belief. As Cassiodorus remarked, although kings should be pious and moderate men, many reges gentium were 'either subject to brute vices or marred by debased religious practice' (EP, CXXXVII. 4). It is tempting to assume that he had in mind heretical rulers of his own day, although he does not say so explictly.

128 See Mischa Meier, Das andere Zeitalter Justinians. Kontingenzerfabrung und Kontingen₹̧bewältigung im 6. Jabrbundert n. Chr. (Göttingen: Vandenhoeck \& Ruprecht, 2004).

129 Meier, Das andere Zeitalter, pp. 101-14, 137-70. See e.g. Nov. Iust. xxx. xi. 2; CJ I. xxvii. 1.1 and 6-7; Nov. Iust. XXXVI, pr. and Nov. Iust. XXXVII, pr., as well as the famous Const. Tanta, cc. 6 and 23 and Const. Deo Auctore, pr. Cf. Maas, 'Roman history and Christian ideology', 25-27; Patrick Amory, People and Identity in Ostrogothic Italy, 485-554 (Cambridge: CUP, 1997), 140-47.

${ }^{130}$ On this, see Heinz Hoffmann, ‘Corippus as a patristic author?’, in Vigiliae Christianae, 43 (1989), 361-77. 
favour, who fought at the side of the Romans just as he had once done for Israel; imperial setbacks, by contrast, were interpreted as temporary tests of their endurance and good faith. ${ }^{131}$ In his account of Justinian's wars, the historian Procopius was much preoccupied with the moral interpretation of the recent past, with questions of historical causality and contingency, divine intervention in human affairs and with the ways to discern its patterns. ${ }^{132}$ He often described the reflections of various actors in the Wars about the reasons for victory and defeat, and about the preconditions for divine support. ${ }^{133}$ But he also weighed Christian assumptions about an economy of merit and retribution against notions of contingency and amoral fate - or, in other words, the inscrutability of God's plans. ${ }^{134}$ The quaestor Junillus addressed similar issues in his Instituta regularia divinae legis, where he attempted to assess the salience and validity of the Bible as a frame of interpretation in the present age. The modes of divine government of human affairs (gubernatio divina) are an important theme in the text, and Junillus carefully explained to his readers how they could learn about God's will and the mechanisms of reward and retribution from the Bible. $^{135}$

As we have seen, Cassiodorus' position on such matters was remarkably nuanced. He carefully avoided directly identifying any particular contemporary group with either the biblical Israel or its enemies. Yet he appears to have been particularly aware of the parallels that could be drawn

131 E.g. Corippus, Iohannis, ed. James Diggle and F.R.D. Goodyear (Cambridge: CUP, 1970), IV. 273-84: 'tu gentes et bella domas, tu conteris arma/impia, tu nostris solitus succurrere rebus [...] sub nostris pedibus Maurorum sterne cateruas/ eripe captiuos saeuis a gentibus Afros/ Romanosque tuos solite miseratus alumnos/cerne pius, nostrosque fauens fac gaudia luctus'; VIII. 348-53: 'gentesque superbas/ frange, precor, uirtute tua: dominumque potentem te solum agnoscant populi, dum conteris hostes/et saluas per bellas tuos'; VII. 98f. ('permitte saepe probari/ipse tuos'). Note V. 522-24, where Corripus alludes to the book of Joshua and the fall of Jericho (Ios x. 12-14): if only God had allowed a similar miracle to occur, that is, if he had lengthened the day of the battle as he had once done, the Moorish gentes would have been completely wiped out (ille dies cunctis supremus gentibus esset/ si mora praecipitem tenuisset prospera solem/ fecit ut ante semel').

132 Cf. Averil Cameron, Procopius and the Sixth Century (London: Duckworth, 1985), 113-19; Dariusz Brodka, Die Geschichtsphilosophie in der spätantiken Historiographie. Studien zu Prokopios von Kaisareia, Agathias von Myrina und Theophylaktos Simokattes (Frankfurt/Main: P. Lang, 2004), pp. 14-61; Michael Whitby, 'Religious views of Procopius and Agathias', in Dariusz Brodka and Michal Stachura eds, Continuity and Change. Studies in Late Antique Historiography (Krakau: Jagiellonian University Press, 2007), 73-93.

133 E.g. Procopius, Bella, v. x. 30-33; VII. viii. 12-19; VII. xxi. 4-11; VIII. 30.

134 Procopius, Bella, II. x. 4-5; VII. xiii. 15-18; VII. xxv. 4-5; VIII. xxxii. 28-30. The matter has been debated in recent years not least with regard to Procopius' religious affiliations, see Anthony Kaldellis, Procopius of Caesarea: Tyranny, History and Philosophy at the End of Antiquity (Philadelphia: University of Pennsylvania Press, 2004), with the comments by Whitby, 'Religious views', 73-82.

135 Junillus Africanus, Instituta regularia divinae legis, ed. and trans. Michael Maas, in Exegesis and Empire, 118-235. See II. 7 and II. 13 on biblical examples for divine punishment and protection, merit and retribution. 
between the military language and imagery of the psalms and the contemporary situation in Italy - but also of the potential danger inherent in an unrestrained use of such imagery to legitimize one's own position. At times, it seems that he deliberately evoked such presentist interpretations precisely to discourage them through the subsequent exegetical argument. ${ }^{136} \mathrm{He}$ forcefully (and repeatedly) reasserted Augustine's view that there was a fundamental difference between the Old and the New Testament in the way in which divine election and guidance manifested themselves. The Old Testament logic could not be seamlessly applied to events in the present, postincarnational age, and it was therefore wrong to continue to expect tangible benefits such as the granting of land or protection in war. ${ }^{137}$ Cassiodorus was thus very careful to delegitimize certain uses of the Bible. Yet, as we have seen, this does not mean that he was not acutely interested in how the biblical text could function as a tool for understanding and interpreting the present. Promoting a reading of the psalms which favoured conversion and integration of religious and political enemies was an important part of his efforts in this regard.

This, moreover, was an immediate concern in the light of contemporary doctrinal controversies. Religious orthodoxy and political legitimacy were intertwined not only in the Old Testament narratives, but also in sixth-century political thought. Imperial propaganda cast Justinian's campaigns against the barbarian gentes in the West as a battle on behalf of the Catholic faith against wicked 'Arians', and Justinian's anti-homoean policy in North Africa could have served to reinforce this message. ${ }^{138}$ It was not uncommon to associate the demise of the Gothic kingdom

\footnotetext{
136 For example, commenting on Psalm 43 (Ps XLIII. 3-4: 'Thy hand destroyed the Gentiles (gentes), and thou plantedst them: thou didst afflict the people, and cast them out/For they got not the possession of the land by their own sword, neither did their own arm save them. But by thy right hand and thy arm, and the light of thy countenance, because thou wast pleased with them'), he reinforced the strong image of a divinely sanctioned conquest of the land: God had driven out the indigineous peoples, to set up the Israelites in their place. Cassiodorus even took up the language of implanting and growth to describe the prosperous relationship that tied Israel to the land (EP, XLIII. 3-4). On the other hand, when translating their deliverance to the gentes into a Christian setting, Cassiodorus used some keywords highly charged with political significance in sixth-century Italy: the chosen people loses liberty (libertas) and possessions (patrimonia) to the hostile gentes (EP, XLIII. 12); a Christian people (populus) is afflicted by 'foreigners' (alienigeni) who lack the right faith, being immersed in 'worldly superstitions' (EP, XLIII. 13).

137 EP, LXXIII. 20: 'In illo enim [i.e, the Old covenant, GH] pollicitationes temporales sunt, ut fuit terra repromissionis et inimicorum subiectio. Talia enim rudi populo debuit concedere, ut ad spiritalia intrepidus potuisset subinde festinare. In nouo autem testamento promittitur imperturbabilis uita, regnum cuius non erit finis, beatitudo perpetua, et Domini contemplatio gloriosa'. In EP, XLIII. 10, Cassiodorus contrasts the experience of Israelites with that of Christian martyrs: 'Nunc autem Deus non egreditur in nirtutibus martyrum, quando eos tribulationibus subdit, et diuersis passionibus tradit. Tunc enim egrediebatur in virtutibus Hebraeorum, quando sine labore prostrati sunt, qui se contra electum populum erigere tentauerunt. Quod ad consolationem sancti populi pertinere non dubium est; ne quis patres suos felicissimos grauiter ferret, cum ipse Domini permissionibus affligatur'. For Augustine's formulation of the problem, see Enarr. in psalmos, LXXIII. 2-3 and 23; XLIII. 5-6 and 10.
}

138 See Dragoş Mirşanu, 'The imperial policy of otherness: Justinian and the Arianism of barbarians as a motive for the recovery of the West', Ephimerides Theologicae Lovanienses, 84 (2008), 477-98, for a survey of the evidence. For Vandal Africa, see Andrew Merrills and Richard Miles, The Vandals (Chicester: Wiley-Blackwell, 2010), 239-50. Cf. Cassiodorus, Variae, XI. xiii. 5, where the personified Roma addresses Justinian in a letter written in the name of the 
with the religious affiliation of the Ostrogothic rulers and elites. Some even interpreted the death of Theoderic as a divine punishment for his heretical attitudes, especially since its circumstances purportedly resembled the infamous end of the heresiarch Arius himself. ${ }^{139}$ In addition, questions of christology and adherence to the doctrine formulated at the council of Chalcedon became increasingly divisive during the reign of Justinian, whose attempts to assure doctrinal unity throughout the empire culminated in the much contested Three Chapters Edict and the Council of Chalcedon $553 .{ }^{140} \mathrm{It}$ is therefore no surprise to find that Cassiodorus frequently used Asaph as a vehicle to instruct his audience about matters of correct faith.

As has often been noted, Cassiodorus in the EP consistently affirmed Nicene orthodoxy against those who, like 'Arians', denied Christ's full divinity. At the same time, he addressed the question of how the human and the divine natures came together in the person of the incarnated Christ, a controversial topic during the Three Chapters Controversy. ${ }^{141}$ Both topics also appear in Cassiodorus' exegesis of Asaph's speeches, not only of those discussed so far, but also in various other psalms of Asaph. Thus, according to Cassiodorus, Asaph incorporated in his plea for the beleaguered Jerusalem in Psalm 73 a passage which prophetically described the miracle of the incarnation and its salvific function for humankind, stressing the son's coeternity and unity with God. ${ }^{142}$ In Psalm 76, christology and the soteriological meaning of the incarnation were identified by Cassiodorus as the topic of the deliberative speech performed by Asaph, who became a vehement advocate of a Chalcedonian two-natures christology. ${ }^{143}$ A particularly vivid example is

senate: 'quid enim pro me nitaris amplius agere, cuius religio, quae tua est, cognoscitur sic florere? [...] Nam si Lybia meruit per te recipere libertatem, crudele est me amittere quam semper visa sum possidere'.

139 Anonymus V alesianus, ed. Ingemar König, Aus der Zeit Theoderichs des Großen. Einleitung, Übersetzung und Edition einer anonymen Quelle (Darmstadt: Wissenschaftliche Buchgesellschaft, 1997), c. 20; Liber pontificalis, Vita Iohannis, ed. Duchesne, I, 275-78, c.6. See Andreas Goltz, Barbar - König - Tyrann. Das Bild Theoderichs in der Überlieferung des 5. bis 9. Jahrbunderts, Millenium-Studien, 12 (Berlin: De Gruyter, 2008), 400-25 and 501-21. On homoean Christianity in Ostrogothic Italy, see Thomas S. Brown, 'The role of Arianism in Ostrogothic Italy: the evidence from Ravenna', in ed. Samuel Barnish and Frederico Marazzi eds, The Ostrogoths from the Migration Period to the Sixth Century (Woodbridge: Boydell, 2007), 417-441.

140 Useful introductions to the topic include Richard Price, 'Introduction' to idem (trans.), The Acts of the Council of Constantinople 553, Translated Texts for Historians 51 (Liverpool: Liverpool University Press, 2009), 1-108; Maas, Exegesis and Empire, 42-64; Celia Chazelle and Catherine Cubitt eds, The Crisis of the Oikumene. The Three Chapters and the Failed Quest for Unity in the Sixth Century Mediterranean (Turnhout: Brepols, 2007).

${ }^{141}$ For discussions of Cassiodorus' theological positions, see Barnish, 'Work of Cassiodorus', 158-65; O’Donnell, Cassiodorus, pp. 166-72; Schlieben, Cassiodors Psalmenkommentar, pp. 175-84; DeSimone, Cassiodoro, 126-47.

142 EP, LXXIII. 12-13. Cf. also EP, LXXIX. 16, where Cassiodorus likewise uses Asaph's plea to affirm Nicene orthodoxy.

143 EP, LXXVI. 7-10. Note the citation of pope Leo I's Codex encyclicus; cf. LXXII. 25, where Cassiodorus explains Asaph's prayer for the coming of the saviour in carefully chosen words: 'ut Deus homo ex duabus et in duabus 
Psalm 81, where Asaph appealed to his community to keep the right faith. Not only did Cassiodorus turn Asaph's speech into an exhortation to the Jews of his own time to convert to Christianity, adding a layer of vigorous anti-Jewish polemic to Asaph's words. He also used the psalm as a vehicle for an equally fierce polemic against both Nestorians and miaphysites, the two groups whose christological positions he considered heretical. ${ }^{144}$ This suggests that Cassiodorus, who supported a (Western) interpretation of Chalcedon with an emphasis on the duality of natures in Christ against the different interpretation by Justinian and the imperial church, may have considered it necessary to distance himself from Nestorian views. At the same time, it confirms the impression that he would not have agreed with Justinian's policy of integration towards the miaphysites and his condemnation of the Three Chapters. ${ }^{145}$ In the context of the difficult relations between the West and the imperial center, persuading others into what Cassiodorus considered the orthodox position was an urgent concern. Cassiodorus used the rhetorical exegesis of the psalms not only as a means of developing patterns of orientation for communities in crisis, but also to reflect on the most pressing theological problems which he himself confronted around the middle of the sixth century.

\section{Conclusion}

The psalms - in a much stronger sense than many other texts - have the potential to shape and transform the self-understanding of their readers. They guide the interpretation of individual experiences by offering a common language which can serve to evaluate and communicate them. As I have attempted to show in this paper, Cassiodorus' analysis of the psalms as orations reinforced this potential of identification. It provided a particularly effective way of persuading his readers to assume the position of the speakers or audience of the psalms, and to refer to themselves the messages and teachings contained in the text. ${ }^{146}$ At the same time, it allowed the

naturis distinctis atque perfectis unus Christus appareat et damnatum lege peccati per gratiam redemptionis absoluat'. On the formula ex duabus et in duabus naturis, see DeSimone, Cassiodoro, 128-32.

144 EP, LXXXI. concl. Against the Nestorians, he brought forward the traditional charge that they divided Christ into two seperate persons, reminding them that this is an error of the same order as believing that there is one intermingled nature, though in the unity of one person'. His polemic against the miaphysites, however, was even more vigorous. After a series of questions challenging their positions, Cassiodorus summed up the flaws of their belief in the one nature of Christ, reminding them of its incongruity with the council of Chalcedon.

145 Cf. Barnish, 'Work of Cassiodorus', 161-63; O’Donnell, Cassiodorus, 170; see also Mario Mazza, 'La Historia tripartita di Flavio Magno Aurelio Cassiodoro senatore: metodi e scopo', in Sandro Leanza ed., Flavio Aurelio Magno Cassiodoro (Soveria Mannelli: Rubbettino, 1984), 210-44 , at 228-29; Agosto, Impiego e definizione, 18-21.

${ }^{146}$ In the preface to the EP, Cassiodorus cited Athanasius of Alexandria's comments to that effect: EP, pr. xvi: 'Quicumque psalmi uerba recitat, quasi propria uerba decantat et tamquam a semetipso conscripta unus psallit et non tamquam alio dicente, aut de alio significante sumit et legit; sed tamquam ipse de semetipso loquens, sic huiusmodi 
exegete to closely follow the movements of the speakers of the psalms, to adopt their role and use their voice to articulate his own views and concerns.

The fact that some of the biblical speakers (such as Asaph) resembled a classical orator and advocate opened up the psalter in a yet more specific sense to readers like Cassiodorus and his peers. Like Cassiodorus, such an audience would possess some rhetorical and possibly also legal training and share experience of and interest in politics as well as in matters of theology and exegesis. Indeed, while the EP could certainly be used as a handbook of rhetorical terms and examples, the sophisticated dialogue between biblical and classical rhetoric to some extent presupposed an audience already knowledgeable in rhetoric, and therefore capable of appreciating its effects. It is intriguing to note that in some of the psalm-orations, Cassiodorus addressed his own audience as niri egregrii, niri prudentissimi or compared the biblical orators to the secular diserti. ${ }^{147}$ This may remind us of the group of diserti who appear in the preface to the Variae as the audience of that work, and whose profile has been described by Jouanaud as that of a courtly elite, most of whom were advocates and distinguished by their rhetorical skills. ${ }^{148}$

These observations can reinforce the notion that the EP was intended to reach not only a monastic audience, but also a wider circle of Latin-speaking intellectuals who were active between Italy and Constantinople around the middle of the sixth century. ${ }^{149}$ We may think, of course, of Pope Vigilius, to whom the text was probably dedicated, and of the clerics in his entourage, some of whom would also have possessed a secular education or some background in law. Among those present in Constantinople was the future pope Pelagius, as well as a number of Italian bishops. ${ }^{150}$ Arator, who also appears among the diserti mentioned in the Variae, is a good example

uerba profert et qualia sunt quae dicuntur, talia uelut ipse agens, ex semetipso loquens, Deo uidetur offere sermones'. Cf. Astell, Cassiodorus's commentary, 68-69; on Athanasius, see Hermann Josef Sieben, 'Athanasius über den Psalter: Analyse seines Briefes an Marcellinus', in Theologie und Pbilosophie, 48 (1973), 157-73; Paul R. Kolbet, 'Athanasius, the psalms, and the reformation of the self', Harvard Theological Review, 99 (2006), 85-101.

147 As noted by van de Vyver, 'Cassiodore', 262 n. 2. See EP, LXXIII. concl. (auditores egregil); LXXXIX. concl. (uiri prudentissimi); note the comparison between secular orators and the biblical speaker in CI. concl. (Isti sapientes, isti diserti, isti reuera gloriosi dicendi sunt oratores, qui talem possessionem uictores accipiunt, de qua inimici aduersitate nullatenus excludantur') and the address to the secular orators in EP, XXXI. 7. Cf. also LXXVI. 2; LXXXV. tit and CVI. 38. On the penitent psalmist as a rhetorical model, see the comments by Astell, 'Cassiodorus' commentary', 61.

148 Jouanaud, 'Pour-qui Cassiodore a-t-il publié?’.

149 Cf. the arguments in Barnish, 'Work of Cassiodorus', 162 and 178-79; Troncarelli, Vivarium, 9-14; Agosto, Impiego e definizione, 19-21; Stoppacci, 'Introduzione', 7-10.

150 Claire Sotinel, 'The Three Chapters and the transformation of Italy', in Celia Chazelle and Catherine Cubitt eds, The Crisis of the Oikumene. The Three Chapters and the Failed Quest for Unity in the Sixth Century Mediterranean (Turnhout: Brepols, 2007), 85-120 at 88-91. 
of the intellectual profile of such a figure who combined both political and ecclesiastical experience. His exegetical poem, with which we began this paper, serves as a reminder of the level of elite (and lay) interest in the Bible, and of the contribution of exegesis to ecclesiastical politics. ${ }^{151}$ But while Arator's reading of Acts was well-suited to support papal claims to authority and primacy by invoking the apostles as role-models for the pope, the rigorous christological position expressed in Cassiodorus' exegesis would eventually put him into disagreement with Vigilius after the latter had consented to the condemnation of the Three Chapters and the proceedings of the Council of Constantinople. Other members of the Italian (senatorial) elite who had emigrated to Constantinople remained involved in the exchange of texts and ideas and in the current political and theological debates as well, for example Cethegus, to whom Cassiodorus addressed the Ordo generis Cassiodoriorum. Cassiodorus was also in touch with some of the North Africans who were engaged in lively polemics against Justinian's ecclesiastical policy. The imperial quaestor Junillus is another example of a courtier turned biblical scholar, who was engaged in political debates similar to those that shaped Cassiodorus' commentary on the psalms. ${ }^{152}$

It should be emphasised that there is no contradiction between a monastic and a broader readership of the EP, or between the spiritual aims of the texts and its political dimension. The $E P$ is a multi-layered text, for which we can trace several purposes and contexts; its audience and reception were not stable in the course of its long history of composition and revision. The commentary as a whole, and the 'rhetorical psalms' specifically, provide a space for spiritual guidance, self-reflection, prayer and meditation. At times, there is a notion of detachment and retreat; but there is also opinionated exegesis, a certain desire for reassurance and justification, and an attempt to offer comments on issues relevant to the contemporary world of the exegete. Cassiodorus used biblical figures such as Moses or Asaph, and the speeches delivered by them, to reflect on and redefine his own position in a time of transition, but he also wrote to persuade his 'hearers' (or readers) as a community.

\footnotetext{
${ }^{151}$ Cassiodorus, Variae, VIII. 12; cf. Jouanaud, 'Pour-qui Cassiodore a-t-il publié?’, 726-28 and see above, p. \$. For lay interest in theological questions, see the examples in Pietri, 'Aristocratie et societé cléricale', 239-41.

${ }^{152}$ For the circuit of Latin literature and polemic in Constantinople during the reign of Justinian, see Cameron, 'Old and New Rome' and cf. above, n. 23. See further Maas, Exegesis and Empire, 8-9, 42-43; Bjornlie, Politics and Tradition, 124-27. On Cassiodorus' contacts in Constantinople, see Barnish, 'Work of Cassiodorus', 158-59; O’Donnell, Cassiodorus, 31-35.
} 
In the EP Cassiodorus constantly negotiated the intersection of biblical and secular oratory. He often did so in order to demonstrate the greater efficacy or veracity of the former, but he also carefully delineated their points of overlap. ${ }^{153}$ This led to the redefinition of classical rhetorical concepts and enabled Cassiodorus to point to the ideal of a Christian rhetorical practice. Its effect, however, was not simply a spiritualisation of secular rhetoric in the sense of its absorption into scriptural studies: rather, secular oratory itself was supposed to become more spiritual and to converge towards Christian standards. It is the tension between biblical and secular rhetoric which allowed Cassiodorus to explore the ways in which the Bible could provide patterns of orientation and identification. It also raised the question of what kind of rhetoric, which language of power, should be used to define the social and legal order of a Christian society, and to reflect on its ethical standards. To modern readers of the EP, this serves as a reminder of the permeability between biblical and secular traditions, and between political and exegetical discourse. Cassiodorus' reading of the psalter was connected with an understanding of exegesis as a means of persuasion. There is, then, a further link between Cassiodorus the politician and author of the Variae and Cassiodorus the exegete: a clear sense of the power of persuasion, and a keen attempt to mediate between different social realms and audiences.

153 Astell, 'Cassiodorus' commentary', 40-41; Agosto, 'Su Cassiodoro', 293-301; with a different interpretation: Quacquarelli, 'L'Elocutio', 398-403. 